\title{
The Pan-Arctic Continental Slope: Sharp Gradients of Physical Processes Affect Pelagic and Benthic Ecosystems
}

\section{OPEN ACCESS}

Edited by:

Dorte Krause-Jensen, Aarhus University, Denmark

Reviewed by:

Céline Heuzé,

University of Gothenburg, Sweden

Paul F. J. Wassmann,

UiT - The Arctic University of Norway,

Norway

*Correspondence: Bodil A. Bluhm bodil.bluhm@uit.no

Specialty section:

This article was submitted to Global Change and the Future Ocean,

a section of the journa

Frontiers in Marine Science

Received: 26 March 2020 Accepted: 29 September 2020

Published: 20 November 2020

Citation:

Bluhm BA, Janout MA Danielson SL, Ellingsen I, Gavrilo M, Grebmeier JM, Hopcroft RR, Iken KB, Ingvaldsen $R B$, Jørgensen $L L$, Kosobokova KN, Kwok R,

Polyakov IV, Renaud PE and Carmack EC (2020) The Pan-Arctic Continental Slope: Sharp Gradients of Physical Processes Affect Pelagic and Benthic Ecosystems.

Front. Mar. Sci. 7:544386. doi: 10.3389/fmars.2020.544386
Bodil A. Bluhm 1*, Markus A. Janout², Seth L. Danielson ${ }^{3}$, Ingrid Ellingsen ${ }^{4}$, Maria Gavrilo5,6, Jacqueline M. Grebmeier ${ }^{7}$, Russell R. Hopcroft ${ }^{3}$, Katrin B. Iken ${ }^{3}$, Randi B. Ingvaldsen ${ }^{1,8,9}$, Lis L. Jørgensen ${ }^{8,9}$, Ksenia N. Kosobokova ${ }^{10}$, Ron Kwok ${ }^{11}$, Igor V. Polyakov ${ }^{12,13}$, Paul E. Renaud ${ }^{14,15}$ and Eddy C. Carmack ${ }^{16}$

${ }^{1}$ Department of Arctic Biology, UiT - The Arctic University of Norway, Tromsø, Norway, ${ }^{2}$ Helmholtz Center, Alfred Wegener Institute for Polar and Marine Research, Bremerhaven, Germany, ${ }^{3}$ College of Fisheries and Ocean Sciences, University of Alaska Fairbanks, Fairbanks, AK, United States, ${ }^{4}$ SINTEF Ocean AS, Trondheim, Norway, ${ }^{5}$ Association Maritime Heritage, Saint Petersburg, Russia, ${ }^{6}$ Arctic and Antarctic Research Institute, Saint Petersburg, Russia, ${ }^{7}$ Chesapeake Biological Laboratory, University of Maryland Center for Environmental Science, Solomons, MD, United States, ${ }^{8}$ Institute of Marine Research, Bergen, Norway, ${ }^{9}$ Institute of Marine Research, Tromsø, Norway, ${ }^{10}$ Shirshov Institute of Oceanology, Russian Academy of Sciences, Moscow, Russia, " ${ }^{11}$ NASA Jet Propulsion Laboratory, La Cañada Flintridge, CA, United States, ${ }^{12}$ International Arctic Research Center, University of Alaska Fairbanks, Fairbanks, AK, United States, ${ }^{13}$ Finnish Meteorological Institute, Helsinki, Finland, ${ }^{14}$ Akvaplan-niva, Tromsø, Norway, ${ }^{15}$ University Centre in Svalbard, Longyearbyen, Norway, ${ }^{16}$ Department of Fisheries and Oceans Canada, Institute of Ocean Sciences, Sydney, BC, Canada

Continental slopes - steep regions between the shelf break and abyssal ocean - play key roles in the climatology and ecology of the Arctic Ocean. Here, through review and synthesis, we find that the narrow slope regions contribute to ecosystem functioning disproportionately to the size of the habitat area ( $6 \%$ of total Arctic Ocean area). Driven by inflows of sub-Arctic waters and steered by topography, boundary currents transport boreal properties and particle loads from the Atlantic and Pacific Oceans along-slope, thus creating both along and cross-slope connectivity gradients in water mass properties and biomass. Drainage of dense, saline shelf water and material within these, and contributions of river and meltwater also shape the characteristics of the slope domain. These and other properties led us to distinguish upper and lower slope domains; the upper slope (shelf break to $\sim 800 \mathrm{~m}$ ) is characterized by stronger currents, warmer sub-surface temperatures, and higher biomass across several trophic levels (especially near inflow areas). In contrast, the lower slope has slower-moving currents, is cooler, and exhibits lower vertical carbon flux and biomass. Distinct zonation of zooplankton, benthic and fish communities result from these differences. Slopes display varying levels of system connectivity: (1) along-slope through property and material transport in boundary currents, (2) cross-slope through upwelling of warm and nutrient rich water and down-welling of dense water and organic rich matter, and (3) vertically through shear and mixing. Slope dynamics also generate separating functions through (1) along-slope and across-slope fronts concentrating biological activity, and (2) vertical gradients in the water column and at the seafloor that maintain distinct physical structure and community turnover. At the upper slope, climatic change is manifested in sea-ice retreat, increased heat and mass transport by sub-Arctic inflows, surface warming, and altered vertical stratification, while the lower slope has yet to display evidence of 
change. Model projections suggest that ongoing physical changes will enhance primary production at the upper slope, with suspected enhancing effects for consumers. We recommend Pan-Arctic monitoring efforts of slopes given that many signals of climate change appear there first and are then transmitted along the slope domain.

Keywords: biological communities, boundary current, climate change, connectivity, continental slopes, panArctic, shelf-basin exchange, vertical and cross-slope gradients

\section{INTRODUCTION: MOTIVATION AND DEFINITIONS}

Continental slopes are a ubiquitous tectonic feature of the global ocean, long recognized for their central climatological and ecological roles at the interface of shelves and basins (Springer et al., 1996; Colloca et al., 2004; Azzellino et al., 2008; Bertram et al., 2017). In general, slope system dynamics are associated with strong vertical and cross-slope gradients that contrast with alongslope bands of relatively more uniform conditions (Cacchione et al., 2002). This situation strongly applies to the Arctic Ocean, as was first noted by oceanographer and geographer Gakkel (1957). Using geomorphological and visual observations from aerial reconnaissance, he identified the Arctic circumpolar continental slope and emphasized its dynamic ice regime, along-slope circulation, and enhanced winter heat loss (Gakkel, 1957). Also recognizing the distinct role of slopes, zoologist Uspenskiy (1973) introduced the term the Arctic ring of life, referring roughly to the continental slope region and highlighting its biological richness compared to adjacent shelf or basin areas, specifically noting more frequent observations of higher trophic level predators including polar bears and narwhals. Given this role, Arctic slopes can be considered as their own pan-Arctic contiguous domain (i.e., functional unit, Carmack and Wassmann, 2006) when considering holistic functioning of the Arctic Ocean. This requires, however, an integration of earlier findings into a panArctic perspective, which currently is lacking.

Regionally focused physical and biological studies targeted around the perimeter of the Arctic basins including at the Barents Sea slope (e.g., Wlodarska-Kowalczuk et al., 2004; PérezHernández et al., 2017; Renner et al., 2018), the Siberian slopes (e.g., Kosobokova et al., 1998; Polyakov et al., 2007; Kosobokova and Hirche, 2009; Janout et al., 2017; Ershova and Kosobokova, 2019), the Chukchi Sea slope (e.g., Grebmeier and Harvey, 2005; Grebmeier et al., 2009), and the Beaufort Sea slope (e.g., Pickart et al., 2013a,b; Majewski et al., 2017; Smoot and Hopcroft, 2017). Here we seek to summarize these and other findings through a pan-Arctic data synthesis and literature review. We begin by introducing relevant terminology and morphological slope structure.

The continental slope is that region starting seaward of the continental shelf break which globally is often marked by the $200 \mathrm{~m}$ isobath (but see modification below) and a strong sloping angle (typically $>4^{\circ}$ ) of the seafloor. The continental slope

Abbreviations: ACBC, Arctic Circumpolar Boundary Current; AW, Atlantic Water; PW, Pacific Water; PSW, Pacific Summer Water; PWW, Pacific Winter Water. extends to the continental rise of the ocean floor which often is at $\sim 2000-2500 \mathrm{~m}$ or where the angle becomes $<\sim 1^{\circ} 25^{\prime}$ (Hay, 2016). Combined, the shelf, slope and rise are commonly referred to as the continental margin. As in other regions of the globe, the slopes of the Arctic Ocean are intersected by numerous canyons, troughs, ridges and straits, resulting in complex morphological, oceanographic and biological structures (Jakobsson et al., 2012). Arctic Ocean here refers to the ocean area bounded by Bering Strait on the Pacific side, by landmasses in the Arctic Ocean interior, and by Fram Strait and the western Barents Sea shelf break on the Atlantic side (Figure 1A). The geological history of the Arctic Ocean has resulted in shelf-break depths that lie at as little as $\sim 60 \mathrm{~m}$ in places off the Siberian shelves to $\sim 400 \mathrm{~m}$ off the Barents Sea (Jakobsson, 2002; Figure 1B). The upper boundary of the continental rise in the Arctic ranges from $\sim 2000$ to $3000 \mathrm{~m}$ depending on location (Jakobsson, 2002). For the purpose of this paper we generally focus on the slope depth range of $\sim 200$ $2500 \mathrm{~m}$ (starting at $\sim 400 \mathrm{~m}$ in the deeper Barents Sea). This area constitutes roughly $6 \%$ of the total Arctic Ocean area.

Property gradients in the narrow band above the slope region are expressed in three directions that we use as guiding structure throughout the present paper: (1) the along-slope (azimuthal) direction around the entire Arctic perimeter, and (2) the vertical direction (downwards) from ocean surface to the seafloor, and (3) the cross-slope (radial in the Arctic) direction from the continental shelf break down-slope (Figure 1C). Beside the three directions, we further distinguish two vertical zones: the upper slope (approximately 200-800 m on the Pacific side and approximately $400-800$ on the Atlantic side), and the lower slope (approximately 800-2500 m) (Figure 1A). The basis for this designation is the dominance of sub-Arctic inflows from the north Atlantic and north Pacific that flow around the basin perimeter above the upper slope (details in section "Physical Oceanography of Arctic Slopes;" Carmack and Wassmann, 2006). The lower boundary of the upper slope is associated with the bottom of the Atlantic layer, defined conventionally - yet somewhat arbitrarily - by the $0^{\circ} \mathrm{C}$ isobath. The lower slope then begins with the transition to the Arctic Deep Water (Aksenov et al., 2011; Pnyushkov et al., 2018), extends to the approximate transition to the continental rise, and is associated with greatly declining and less advected biomass (Kosobokova et al., 2011; Vedenin et al., 2018).

Once we have described bio-physical features along the above gradients and zones, we integrate physical (section "Physical Oceanography of Arctic Slopes") and biological (section "Gradients in Biological Communities at Arctic Slopes") information to conceptualize the ecological functions that Arctic 
A

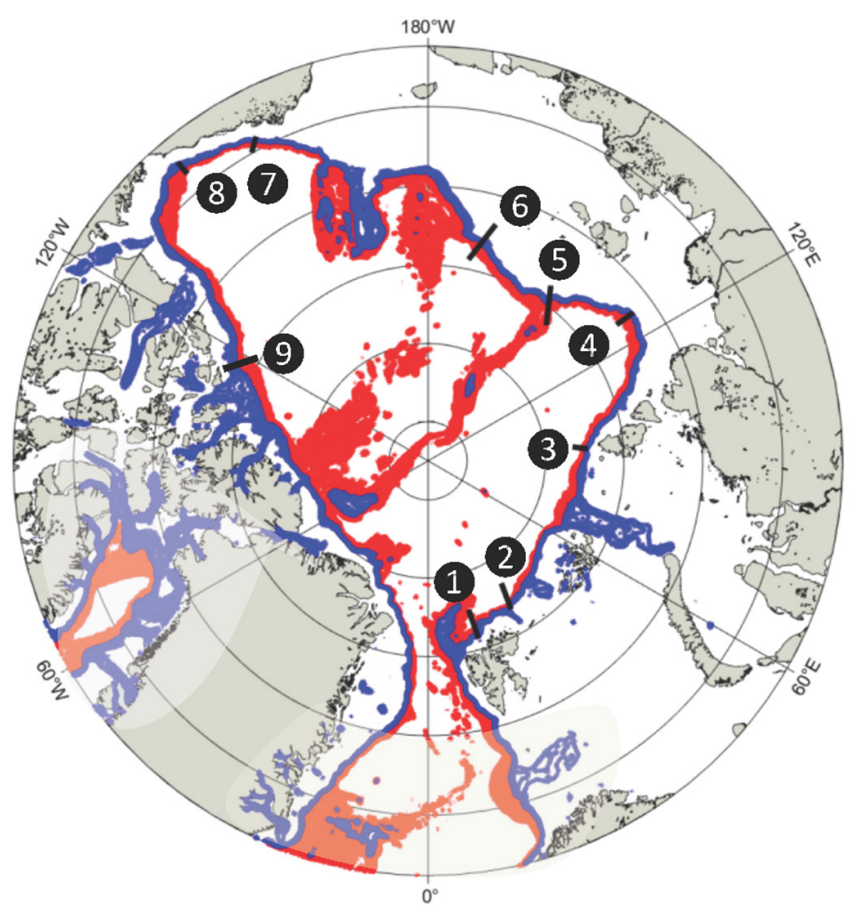

C

B

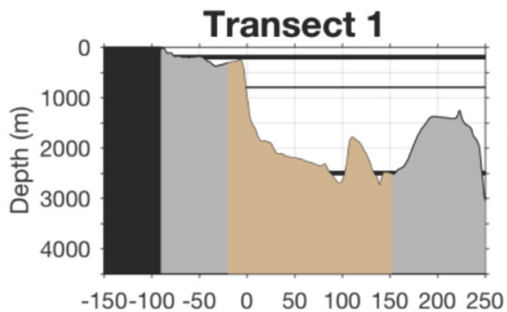

Transect 4
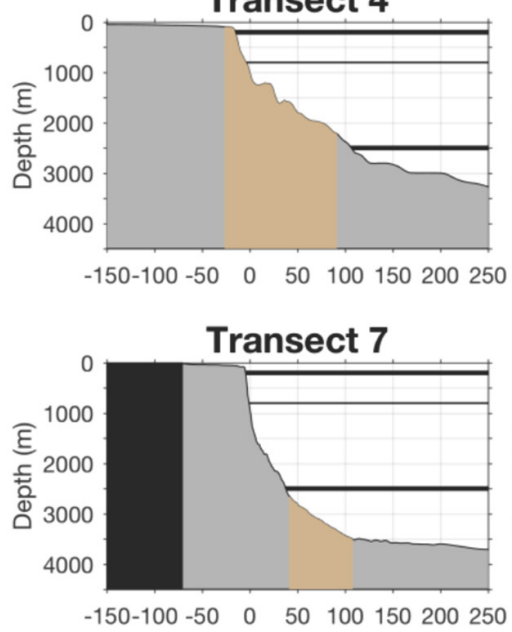

Transect 2

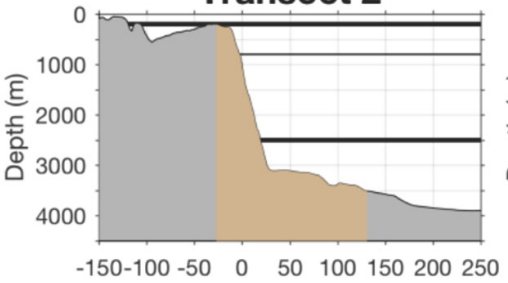

Transect 5

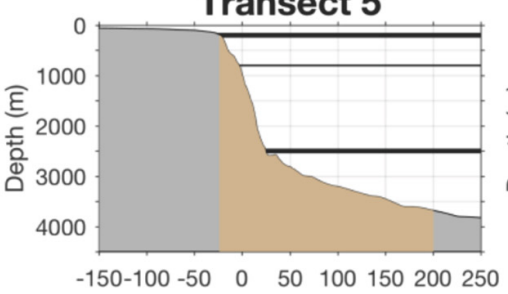

Transect 8

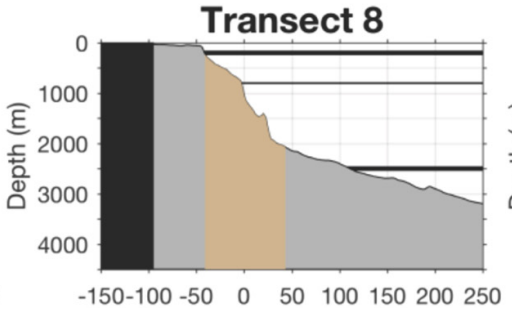

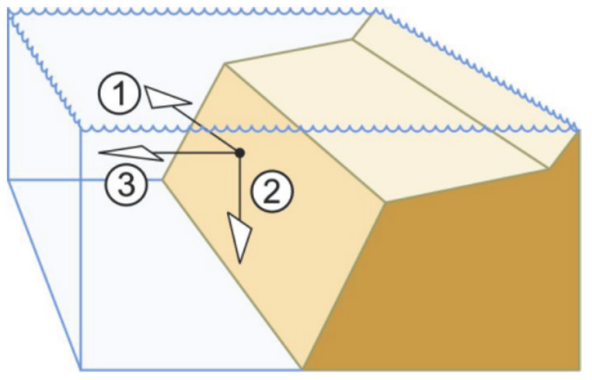

Transect 3

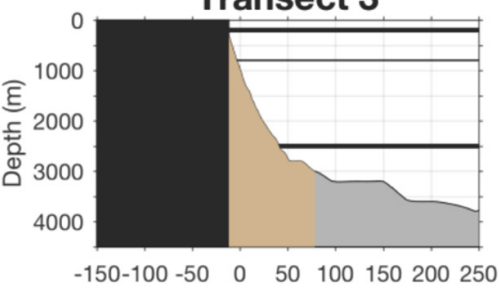

Transect 6
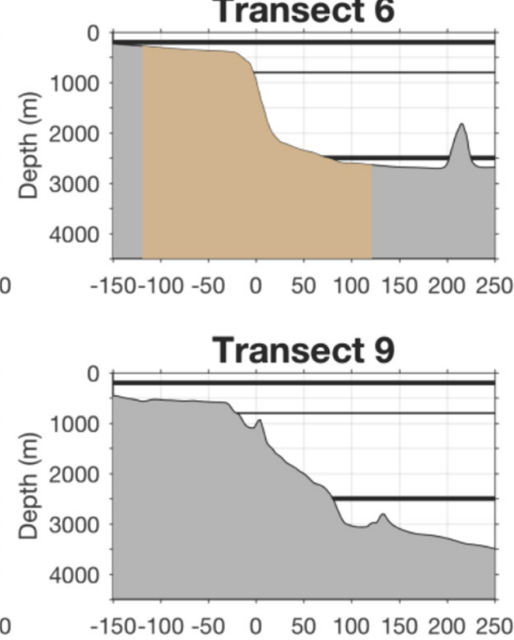

FIGURE 1 | The Pan-Arctic slopes. (A) Upper slope domain (blue), here shown as the 400-800 $\mathrm{m}$ band, and lower slope domain (red), here shown as the 800-2000 $\mathrm{m}$ band. (B) Bathymetric cross sections representing pan-Arctic slopes. Transect locations match those in Figure 2 (with the exception of transect 9 ) and have been centered so that $X=0$ is on the $1000 \mathrm{~m}$ isobaths for consistency. Sections are trimmed to show -150 to $+250 \mathrm{~km}$ from the $1000 \mathrm{~m}$ isobath. Gray shows the whole profile while brown is the section that overlaps with temperature transects in Figure 2; black is land. Black horizontal lines mark the slope range focused on in the present paper; gray line marks the lower boundary of the Atlantic Layer (designated as the lower boundary of the "upper slope domain"). (C) The three dimensions of Arctic continental slopes considered in this paper: (1) along-slope (azimuthal) along the basin perimeter, (2) vertical (ocean surface to seafloor), (3) cross-slope (from the shelf break off-shore down slope). 
continental slopes add to the Arctic Ocean system in section "Functions of the Slope: System Connectivity vs. Separation." Some of these functions result from the geomorphology of continental slopes in general (Nash et al., 2004; Levin and Dayton, 2009), and others from specific regional hydrographic settings in the Arctic in particular. These functions can act through both connecting and separating processes between adjacent shelves and basins. Finally, in section "Towards a Future Arctic Slope System," we summarize ongoing climatic changes overlying the Arctic slopes; specifically warming (Polyakov et al., 2020a, this issue) and sea ice loss (Kwok et al., 2013), and then briefly present a modeling exercise to investigate potential associated biological changes.

\section{PHYSICAL OCEANOGRAPHY OF ARCTIC SLOPES}

\section{Along-Slope: Boundary Currents}

The Arctic continental slopes provide a "handrail" for incoming sub-Arctic waters, meaning the slope topography steers these waters counterclockwise (cyclonically) around the basin perimeter. The most prominent pan-Arctic circulation feature transporting inflowing Atlantic Water (AW) is the Arctic Circumpolar Boundary Current (ACBC), which funnels Atlantic-origin water as a narrow, contiguous stream that encircles all Arctic Basins (Aagaard, 1989; Rudels et al., 1994; Aksenov et al., 2011). Similar dynamics hold for incoming waters of Pacific origin, but these are more complicated and largely retained within the Amerasian Basin (McLaughlin et al., 1996; Shimada et al., 2006; Pickart et al., 2009, 2013a,b; Aksenov et al., 2016). Such boundary currents are common to continental slopes globally (Huthnance, 1981) but are especially strong in the Arctic owing to the joint effects of the increase in Coriolis force with latitude and the exposure to ice-cover. The ACBC initially forms from the entry of warm and saline AW through Fram Strait (as the Fram Strait Branch) and then flows along the northern Barents Sea slope. A second branch of AW crosses the Barents Sea (the Barents Sea Branch), then enters the Arctic Ocean, mainly through St. Anna Trough, where the two branches remerge in the northern Kara Sea slope (Hanzlick and Aagaard, 1980). These are then joined by the drainage of Siberian Shelf waters before continuing around the Arctic Ocean perimeter (Aksenov et al., 2011). This circulation pattern extends through the full depth of the pan-Arctic continental slope. Current velocities, however, are strongest at the upper slope, especially along the Barents Sea slope (peak flow rates of $>20 \mathrm{~cm} / \mathrm{s}$ ), and noticeably weaker in deeper water and along the basin perimeter on the Amerasian side (Aksenov et al., 2011; Pnyushkov et al., 2015; Menze et al., 2019). In the surface layer, the subsurface ACBC can be opposed by wind-driven circulation, such as the clockwise-flowing Beaufort Gyre (Proshutinsky et al., 2009).

To demonstrate the progressive evolution of AW properties while flowing counterclockwise along the upper pan-Arctic slope we here use a near-synoptic view of the Arctic shelfto-slope structure in summer, 2015, in temperature sections (Figure 2), and temperature/salinity plots (Figures $3 \mathbf{A}, \mathbf{B}$ ), and vertical salinity profiles (Figure $3 \mathrm{C}$ ). Initially, AW outcrops at the surface in Fram Strait and north of Svalbard; typically, in winter (Randelhoff et al., 2018; Renner et al., 2018). When sea ice melts, either due to contact with the inflowing warm AW, or due to solar input during spring and summer, a cold and fresh (and less dense) surface layer develops (Untersteiner, 1988; Rudels et al., 2013 , 2014). When this happens in summer, there is substantial solar heating of the shallow, seasonal surface layer, making it even warmer than the AW below (e.g., north of the Svalbard slope) [Figures 2(1), 3A(1); note that an expanded temperature and salinity range would reveal warmer and fresher varieties of surface water north of the Svalbard slope]. Slightly further east the core of the AW subducts and becomes capped by the cold and fresh near-surface layer [Figures 2(2), 3A(2)], and subsequently cools and deepens during its translation along the slopes of the Barents and Kara Seas [Figures 2(3), 3A(3),B]. Just upstream of $95^{\circ} \mathrm{E}$ at St. Anna Trough, the Barents Sea-modified branch of AW debouches the continental slope region and interacts with the Fram Strait Branch. As a result, the AW core is further cooled, with maximum temperatures decreasing by at least $1^{\circ} \mathrm{C}$, while also gradually freshening [Figures $2(4,5), \mathbf{3 A}(4,5)$ ]. Further east in the Laptev Sea in particular, cold and saline waters created in strong polynyas that form in winter and spring (Bareiss and Görgen, 2005) cascade down the continental slope and contribute to the halocline complex (Aagaard et al., 1981; Martin and Cavalieri, 1989; Ivanov and Golovin, 2007; Walsh et al., 2007). Numerous canyons and passages in the Severnaya Zemlya region $\left(100-110^{\circ} \mathrm{E}\right)$ (Shokalsky Strait, Vilkitsky Strait) guide the export of these cold and dense waters toward the slopes (Janout et al., $2015,2017)$. The injection of these waters then results in further cooling of the AW as it continues eastward along the Siberian shelves [Figures 2(6), 3A(6)]. At the same time, large rivers dilute the Arctic Ocean surface and strengthen the fresh cap over the AW as it propagates eastward along-slope. Note that prior to leaving the Nansen Basin the salinity gradient below the core (i.e., $\mathrm{T}_{\max }$ ) of $\mathrm{AW}$ is negative, thus permitting salt-fingering, while beyond $135^{\circ} \mathrm{E}$ it is positive. Upon reaching the Chukchi Sea the joint effects of the Pacific Water (PW) inflow and the clockwise wind field over the Beaufort Sea result in a further deepening of the AW core [Figures 2(7,8), 3A(7)]. Beyond this point the AW begins its exit into the Greenland Sea via the western Fram Strait and the East Greenland Current (Rudels et al., 2012; Håvik et al., 2017). During its propagation along the Arctic slopes, the $\mathrm{AW}$ thus decreases from a $>3^{\circ} \mathrm{C}$ warm, several hundred-meterthick layer near the inflow region to a thinning, $<1^{\circ} \mathrm{C}$-layer that is centered around a depth of $400 \mathrm{~m}$ along the slope of the Canada Basin (Figures 4A,B). Also, along this transit the salinity of the core layer, referenced to the surface, freshens substantially from about 35.0 to 34.8 (Figure $3 \mathbf{B}$ ), the density decreases slightly from about 27.94 to 27.92, while stratification (i.e., Brunt-Vaisala buoyancy frequency) of the overlying water column increases by a factor of 3-10 (cf. Polyakov et al., 2018).

Boundary currents also form along the Pacific Arctic slopes because of inflowing PW through Bering Strait, but with different flow patterns than those of the AW (Figure 4B). Incoming PW is strongly modified by seasonal processes while crossing the broad Bering and Chukchi Sea shelves, so that it arrives at the shelf slope boundary as either Pacific Summer Water (PSW; relatively warm and fresh) or Pacific Winter Water (PWW; colder 


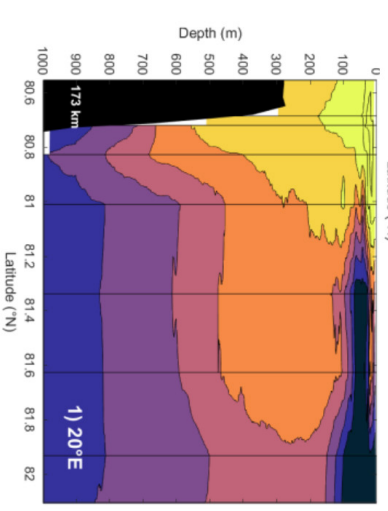

Depth (m)

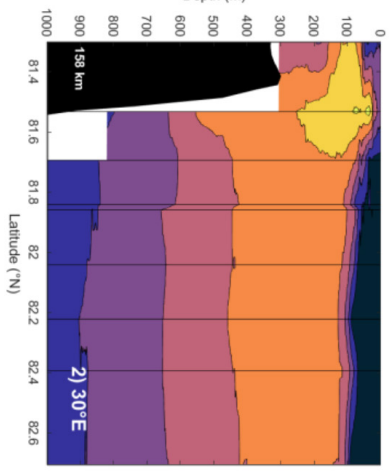

Depth (m)

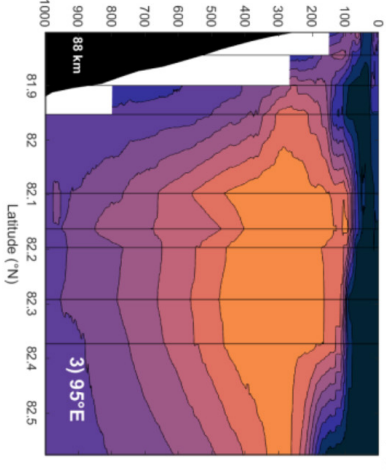

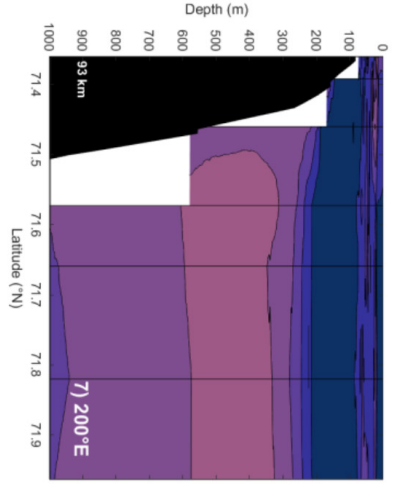
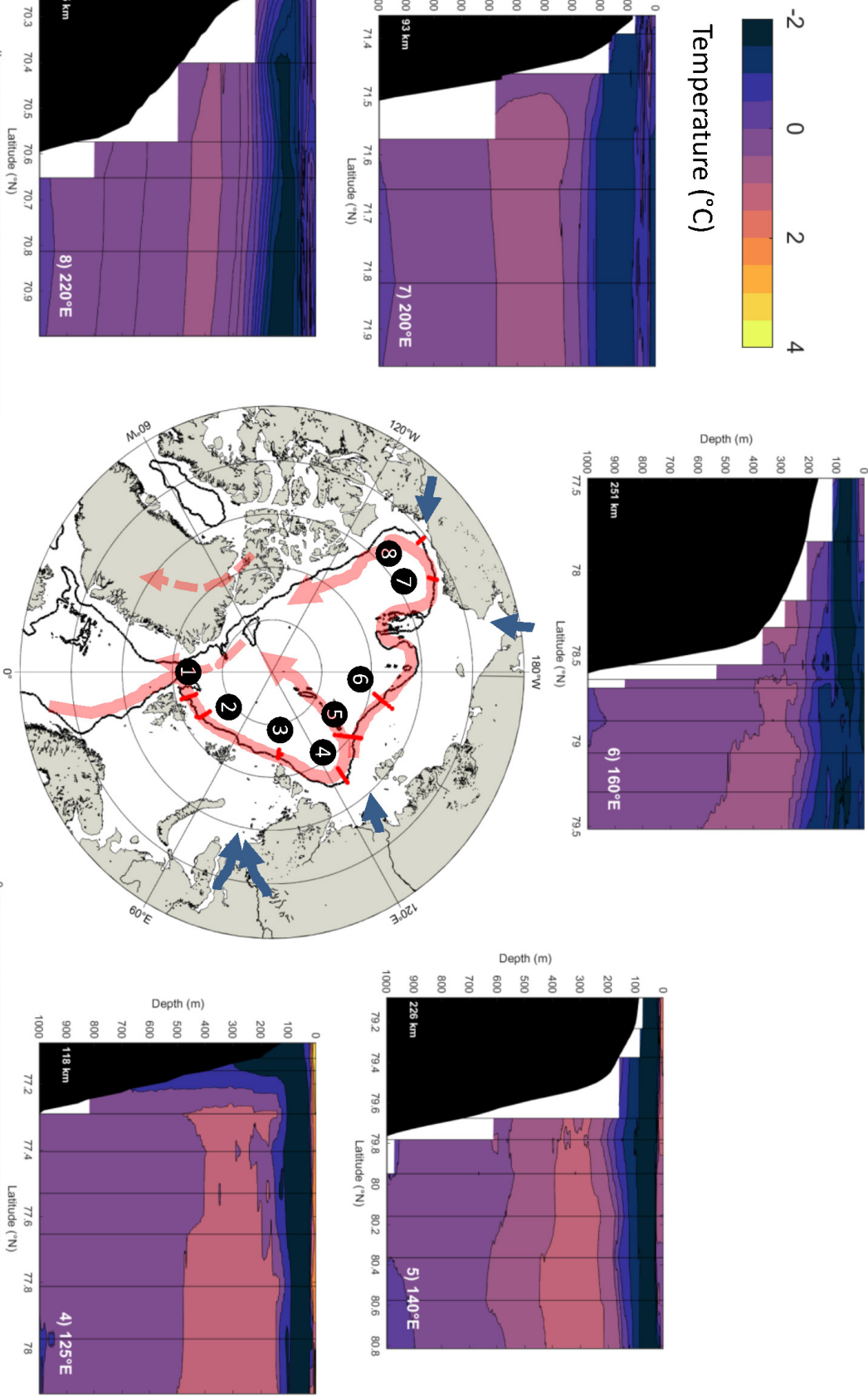

FIGURE 2 | Pan-Arctic potential temperature transects of the Arctic shelf-to-slope structure in summer of 2015 showing Atlantic Water (AW) position over the slopes: transects are the same as in Figure 1. Warm AW near the surface in Fram Strait / north of Svalbard (1, 2) becomes capped by a colder and fresher surface, and gradually cools and deepens along the slopes of the Barents, Kara, and Laptev Seas $(3,4,5)$. Canyons and passages bring cold and dense shelf water to the slopes, further cooling the AW on the E Siberian shelf (6). Pacific Water inflow and clockwise wind fields over the Beaufort Sea result in further deepening of the AW core (7, 8) before beginning to move towards exiting via western Fram Strait and the East Greenland current. We lack oceanographic data from transect (9) in Figure $\mathbf{1}$.

and more saline) (Weingartner et al., 2005; Pickart et al., 2016). Much of PSW exits via Barrow Canyon, while smaller fractions exit through Herald Canyon and Central Channel (Weingartner et al., 2017). Some fraction turns eastward as a subsurface flow at $\sim 40-80 \mathrm{~m}$ along the shelf-slope boundary, referred to either as the Beaufort Undercurrent (Aagaard, 1984) or shelf-break jet (Pickart et al., 2005; Figure 4B). This thermohaline feature differs from the highly transient, wind-driven jet that forms at the Pacific Arctic slopes during upwelling and downwelling events (Williams and Carmack, 2015). The remaining fraction of PSW exiting 


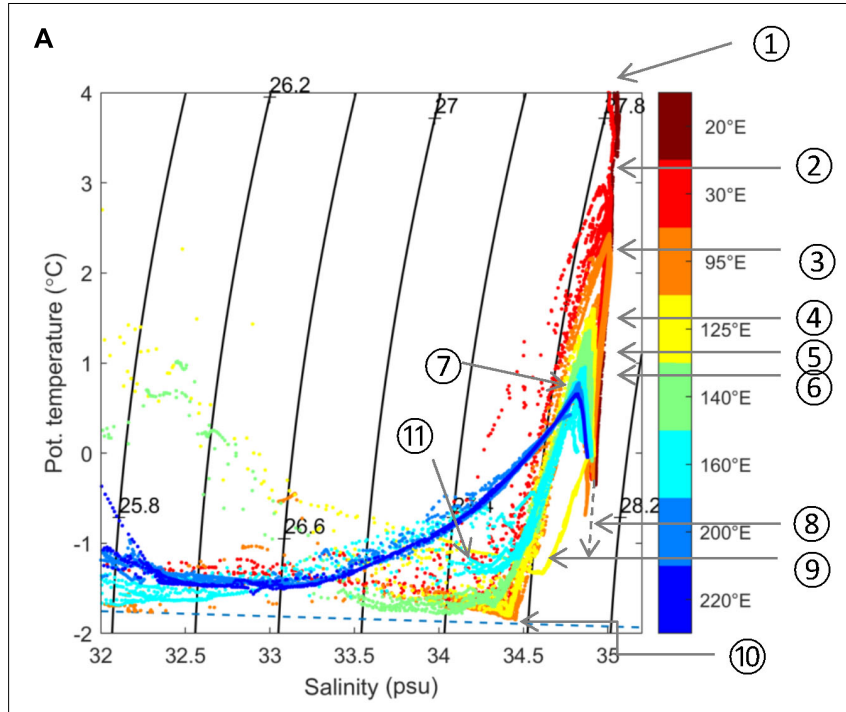

B

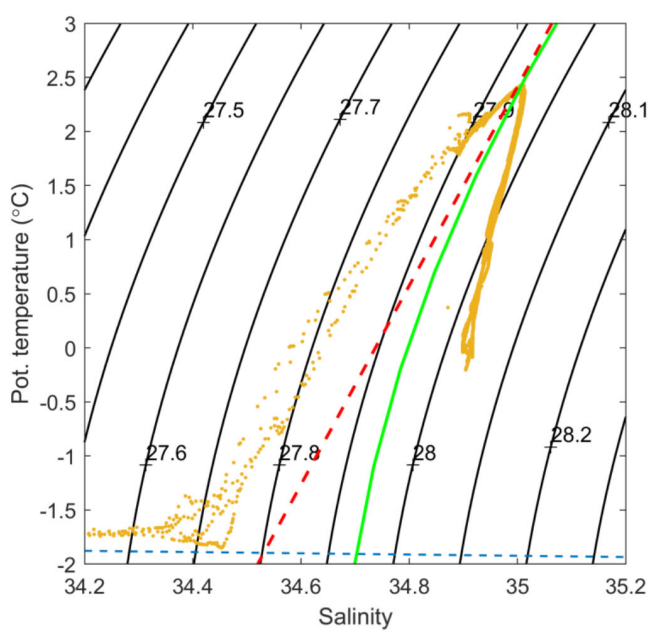

C

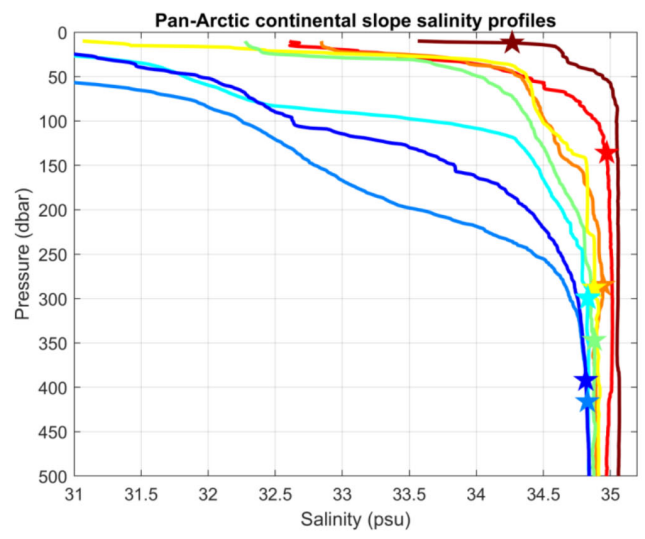

FIGURE 3 | Continued
FIGURE 3 | Water mass structure over pan-Arctic slopes.

(A) Temperature/Salinity diagrams for selected slope transects 1-8 shown in

Figure 2 for temperature range $-2-4^{\circ} \mathrm{C}$ and salinity range 32.0-35.2.

Individual stations are color-coded by longitude and refer to transect locations

in Figure 2. Numbers in circles (from 1 to 11), in contrast, refer to the following noteworthy features: (1) crossing the Fram Strait Branch (FSB) northwest of Svalbard prior to encountering ice and Arctic surface water, (2) flowing north of Svalbard subsequent to mixing with and subduction of the core of AW below Artic surface water, (3) the core of AW as it continues to cool and freshen along the Barents Sea slope, (4) water from the Barents Sea Branch (BSB) entering via the St. Anna Trough and converging with the FSB, (5) the warm core of the FSB is cooled, freshened and displaced offshore by the BSB, (6) continued cooling and freshening of the AW core along the Siberian shelves, (7) after crossing the Lomonosov Ridge into the Amerasian Basin, (8) the Atlantic-Pacific halocline front where the gray dashed line indicates the mixing line leading to bottom water in the Nansen basin, (9) the T/S correlation curve for modified AW in the BSB prior upon entering the slope domain through St. Anna Trough, and 10) the maximum salinity reached by Cold Halocline Water. (B) T/S for salinity range 34.2-35.2. Orange: T/S from $95^{\circ} \mathrm{E}$. The red dashed line indicates a straight line tangent to $\sigma_{0}=27.94 \mathrm{~kg} \mathrm{~m}^{-3}$; the point at which this line crosses the freezing temperature yields the maximum salinity that surface waters can reach without triggering the caballing instability (34.53) (cf. Fofonof, 1956). (C) Vertical profiles of salinity for slope stations at transects 1-8 from Figure 2 showing progressive freshening. Stars show the depth of the AW core $\left(T_{\max }\right)$ at each station location; note the progressive deepening of the AW core layer as the boundary current progresses around the Arctic basin.

through Barrow Canyon is drawn offshore into the Beaufort Gyre (Shimada et al., 2006) or ejected off-slope by mesoscale eddies (cf. D'Asaro, 1988; Mathis et al., 2007). In addition to PW joining the shelf-break jet, recent studies indicate that a portion of the PWW turns westward over the slope, forming a boundary current that appears to follow the clockwise circulation pattern of the Beaufort Gyre (Corlett and Pickard, 2017; Spall et al., 2018; Li et al., 2019). Long-term observations in the Canada Basin showed an increase in PWW volume by $18 \%$ from 2002 to 2016 (Zhong et al., 2019), thus underlining the increasing role of PWW as a sub-surface freshwater source to the Beaufort Gyre.

In contrast to the dynamic shelf break and upper slope described thus far, the lower slope lacks large gradients and is comparatively quiescent. Below the core of AW and to the depths of the Lomonosov and Alpha-Mendeleev ridges, potential temperature decreases and salinity increases slightly to the seabed along the lower slope (Timmermans et al., 2003; Björk and Winsor, 2006). The lower slope has current velocities that are generally below $2 \mathrm{~cm} / \mathrm{s}$ and is dominated by smaller-scale processes (Bluhm et al., 2015 and references therein). Visual evidences of abundant and persistent animal tracks despite low faunal densities support the notion of extremely low flow rates (Zhulay et al., 2019). Overall, little is actually known about the lower slope environment and more work is required to characterize it.

\section{Vertical and Cross-Slope Structure and Processes}

The water column above the slopes is generally salt-stratified, with relatively fresh surface water and a halocline above the Atlantic Layer (Figure 3C). Specifically, the combination of 

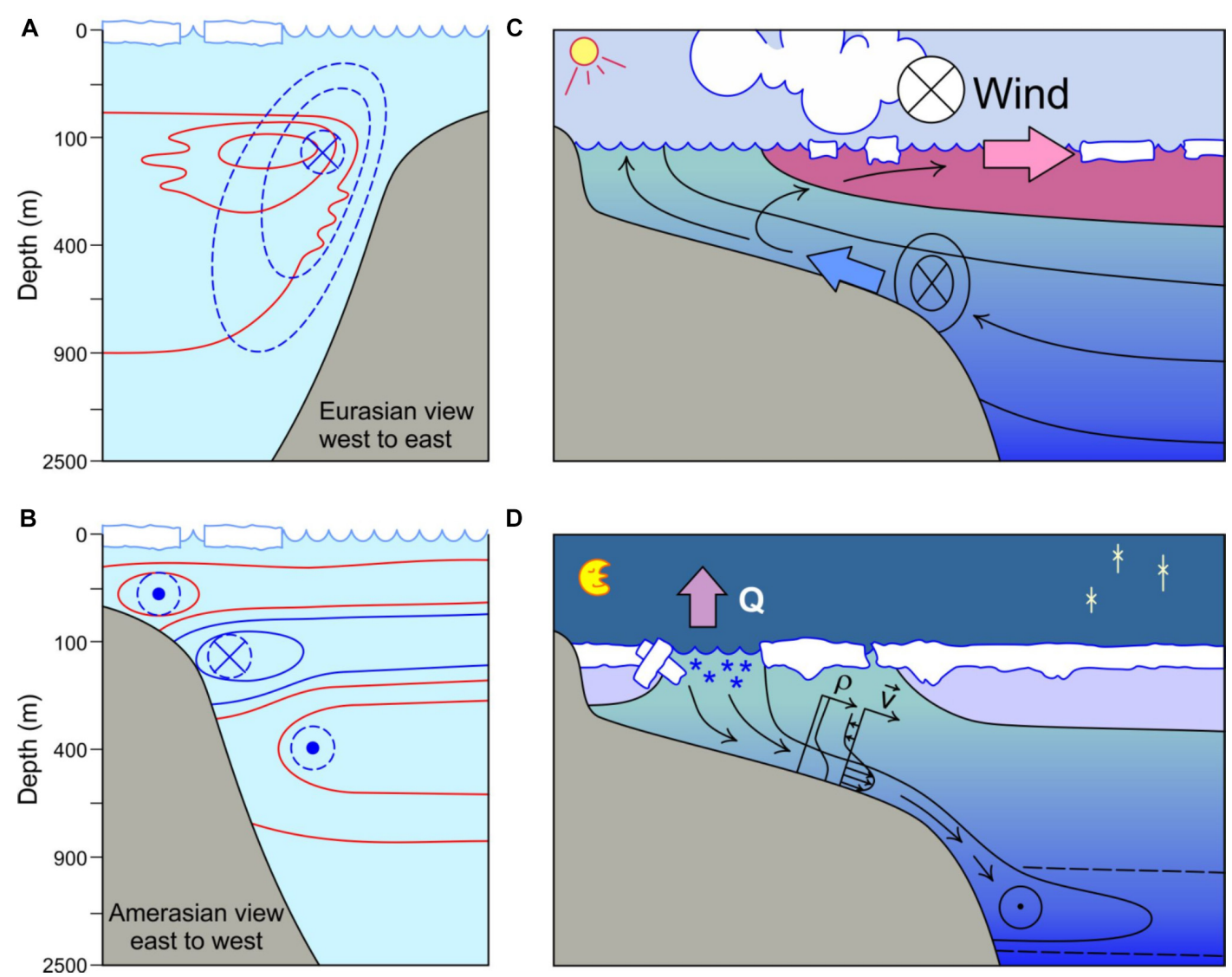

D

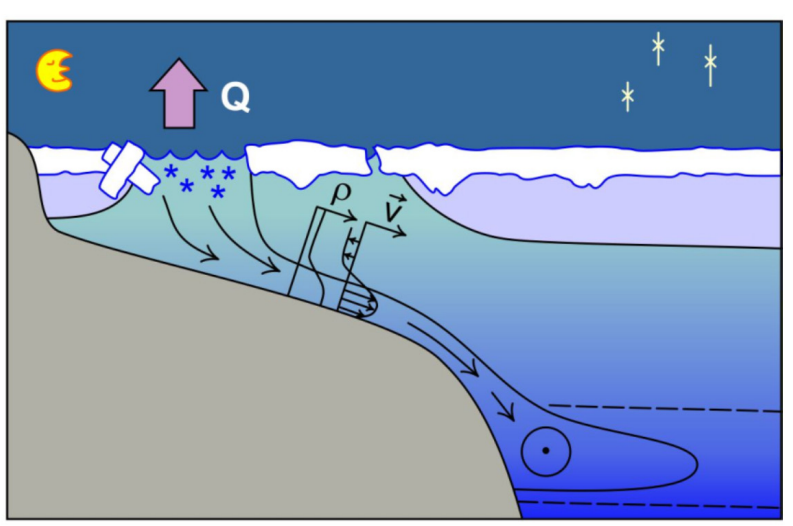

FIGURE 4 | Conceptual model showing connecting functions of Arctic continental slopes. (A) Idealized structures of the single boundary current at the Eurasian (Siberian) slope and (B) multiple currents at the Amerasian (Beaufort) slope with upper circle denoting shallow, eastward directed flow of Pacific Summer Water, middle circle showing westward directed flow of colder Pacific Winter Water along the upper slope, and lower circle denoting eastward directed AW. The Eurasian view is from the west to the east; the Amerasian view is from the east to the west. Dashed lines denote velocities, while solid lines depict temperature; depth is shown as a square root scale. (C) Upwelling circulation across a shelf with a shallow shelf break, typical of interior shelves. Here the wind is directed into the panel such that the offshore Ekman transport (pink arrow) is compensated by an onshore flow across the shelf/slope boundary (blue arrow); in this case drawing cooler and presumably nutrient-rich waters onto the shelf. Also shown is a transient shelf/slope break jet, or bottom-boundary layer, also directed into the panel. (D) Brine release during sea ice formation and brine-driven circulation across a shelf and down slope. $Q$ is heat flux $(Q)$ and stars indicate frazil ice formation. Inset profiles are shown for density $(\rho)$ and velocity $(v)$. Circles with dots denote flow out of the panel while circles with crosses denote flow into the panel.

freshwater inputs (seasonal sea ice melt, river water, glacial melt water), surface warming and wind-driven mixing result in a seasonal mixed layer (approximately 40-60 m thick). Underneath it, the halocline complex with (Amerasian slopes) or without PW (Eurasian slopes) (McLaughlin et al., 1996; Rudels et al., 2004) forms a boundary that inhibits upward mixing of nutrients (Codispoti et al., 2013), but see section "Separation Generates and Maintains Structure." Multiple steps in the halocline reflect the different sources that supply water to the halocline, e.g., sea ice melt, river discharge, net precipitation, Pacific inflows and Siberian shelf drainage (Brown et al., 2020). The Atlantic Layer below (to $\sim 800 \mathrm{~m}$ ) is warmer and saltier than the underlying Arctic Ocean Deep Water at the lower slope (Aagaard et al., 1985; Rudels et al., 2012). Variations in the vertical stratification resulting from this layering are primarily a result of the interplay of the warm and salty AW, sea ice melt, incoming rivers and the PW inflow, leading to distinct regimes in vertical stratification along the pan-Arctic slope. These can be tied directly to the shelf typology as discussed by Carmack and Wassmann (2006) and Bluhm et al. (2015): At the slope of the Atlantic inflow shelf region north of Svalbard/Barents Sea where AW seasonally extends fully to the surface, a halocline is initially lacking and is first established by the interaction of AW with sea ice melt water (Figure 3C). At the slopes of the interior shelves subsequent to the St. Anna Trough Siberian river water reaches the slopes, and brine-enriched Siberian shelf waters flowing offshelf form additional halocline waters. At the slopes of the Pacific inflow shelf (the Chukchi Sea) and into the Pacific Interior shelf (Beaufort Sea) the combined effects of the PW inflow and the Beaufort Gyre circulation greatly increase vertical stratification. And finally, at the slopes of the outflow shelves (the Canadian Arctic Archipelago and the northern Greenland slopes) vertical stratification is thought to remain largely unchanged until waters exit along East Greenland. Increasing glacial runoff to the East Greenland shelf, however, may in the future not only increase the local stratification and is likely to speed up the coastal circulation 
for instance in the wind- and buoyancy-forced East Greenland Coastal Current (Sutherland and Pickart, 2008), but also already has the potential to reach the outer shelf and boundary currents (Hendry et al., 2019). Overall, the outflow shelves are strongly impacted by liquid and solid freshwater export from the Arctic Ocean (Michel et al., 2015), and will likely continue to receive additional freshwater loads from glacial runoff with not yet understood impacts on the slope system.

The above described progressive cooling and freshening in the along-slope direction from Eurasian to Amerasian slopes involves numerous vertical and cross-slope displacements of water mass layering and frontal zone structures. For example, vertical displacements, forced by winds, tides, eddies and seasonal heating and cooling all give rise to significant $\left(>1^{\circ} \mathrm{C}\right)$ temperature fluctuations at any given location on the upper slope (Baumann et al., 2018). Properties of the upper slope domain are especially impacted by cross-slope mechanisms that act to break the dynamic barrier between shelves and the Arctic Ocean's interior, such as upwelling and brine drainage (see section "Connectivity") (Figures 4A,B). Cross-slope exchange is especially amplified at sudden topographic junctions (straits, canyons, relaxations in the slope angle, etc.). One example is where Barrow Canyon intersects the Beaufort/Chukchi Sea continental slope at nearly a right angle, and where on average $25-50 \%$ of northward flowing PW exits the Chukchi shelf (Itoh et al., 2013; Weingartner et al., 2017). Downcanyon flow can only partially adjust to the sharply turning isobaths when the canyon abuts the slope, thus leading to an overshoot and injection of shelf waters onto the upper slope or into the basin. Consequently, regions of cross-slope flow often are associated with the formation of energetic eddies that carry mass, heat, and biogeochemical constituents from the shelf regions to the slope and the basin interior (Gawarkiewicz and Chapman, 1995; Mathis et al., 2007; Hattermann et al., 2016; Våge et al., 2016; Pnyushkov et al., 2018). Another example occurs in the Mackenzie Trough off the Canadian Beaufort shelf, where upwelling-favorable winds draw Atlantic waters as much as $400 \mathrm{~m}$ or more up canyon, which subsequently collapse back into the basin, generating eastward propagating internal Kelvin waves along the slope (Carmack and Kulikov, 1998). Slope angle also appears to govern contrasts in shelf-basin exchange; for example, the basin seaward of the steep Laptev Sea slope shows comparatively little signal of Laptev Sea shelf waters egressing seaward, suggesting that shelf-basin exchange here is constrained. In contrast, further east along the wide East Siberian slope, enhanced transport of shelf waters into the basin is found (Anderson et al., 2017). These exchange windows are particularly relevant near the large rivers, as freshwater is an important contribution for the water column stratification of the Arctic Ocean (Carmack et al., 2016), as discussed further in section "Functions of the Slope: System Connectivity vs. Separation."

\section{GRADIENTS IN BIOLOGICAL COMMUNITIES AT ARCTIC SLOPES}

Gradients in standing stock, community composition, and production are prominent at slope areas, both vertically in the water column and across-slope for both pelagic and seafloor communities. Spatial patterns in primary production levels reflect oceanographic patterns and processes described in section "Physical Oceanography of Arctic Slopes," and contribute to driving spatial patterns in standing stocks across trophic levels [of which we here consider zooplankton and benthos (section "Gradients in Primary Production and Lower Trophic Level Biomass"), and fishes, seabirds and marine mammals (section "Higher Trophic Level Biomass and Distribution") and their community composition (section "Community Structure and Biodiversity Trends")]. Geographical variation in each trophic level is discussed beginning at the Atlantic gateway slope and proceeding eastward around the basin perimeter, as data coverage allows.

\section{Gradients in Primary Production and Lower Trophic Level Biomass}

The hydrography over the slopes described above, combined with the steep depth gradient, provide the backdrop for biological gradients along and across the Arctic slopes. In the alongslope direction, levels of primary production vary as a result of gradients in nutrient concentrations, supply and sources. The AW inflow is the primary nutrient source for the Eurasian Arctic slope (Codispoti et al., 2013) and these advective inputs fuel gross primary production levels above the slope northwest of Svalbard of 0.1-0.9 $\mathrm{mg} \mathrm{C} \mathrm{m}^{-2} \mathrm{~d}^{-1}$ (May and August, Svensen et al., 2019), with annual estimates of $\sim 70-100 \mathrm{~g} \mathrm{C} \mathrm{m}^{-2}$ year $^{-1}$ for that area (Slagstad et al., 2011; Frey et al., 2018). In the slope areas of the Siberian and North-American interior shelves, the large rivers add only limited amounts of nutrients (specifically nitrogen and silicic acid, Codispoti et al., 2013), but introduce substantial loads of CDOM and inorganic sediments which can degrade the light regime and limit primary production (Popova et al., 2012). As a result of this and increasing distance from sub-Arctic inputs along the basin perimeter, primary production levels at the slope in these interior shelf regions are less than $\sim 30 \mathrm{~g} \mathrm{C} \mathrm{m}^{-2}$ year $^{-1}$ (Slagstad et al., 2011; Matrai et al., 2013). By comparison, near the Pacific inflow, nutrient-rich PW enhances production to levels of $\sim 170 \mathrm{~g} \mathrm{C} \mathrm{m}^{-2}$ year $^{-1}$ on the Chukchi slope (Hill et al., 2018). Then, production drops off sharply in the Beaufort Sea $(\sim 90 \mathrm{~g}$ $\mathrm{C} \mathrm{m}{ }^{-2}$ year $^{-1}$, Hill et al., 2018) and over the slopes towards the Amerasian Basin ( 15-30 $\mathrm{g} \mathrm{C} \mathrm{m}^{-2}$ year $^{-1}$, Carmack et al., 2004; Frey et al., 2018). Primary production levels along the slopes of the outflow shelves are comparatively poorly quantified, but tend to be lower than in inflow shelves $\left(\sim 60 \mathrm{~g} \mathrm{C} \mathrm{m}^{-2}\right.$ year $^{-1}$ and dropping off beyond the slopes; Matrai et al., 2013; Michel et al., 2015; Frey et al., 2018). We note, however, that changes in primary productivity are ongoing and predicted (see section "Towards a Future Arctic Slope System") and unusual peaks in algal biomass were for example recently observed along the Greenland Sea slope (Frey et al., 2019).

Enhanced abundance and biomass of zooplankton, benthos, and upper trophic level consumer communities are apparent over the inflow slopes and to some degree beyond. For zooplankton, this enhancement is evident in cross-slope transects of integrated mesozooplankton biomass in both the Eurasian and Amerasian sectors of the slope (Figure 5A). Vertically 


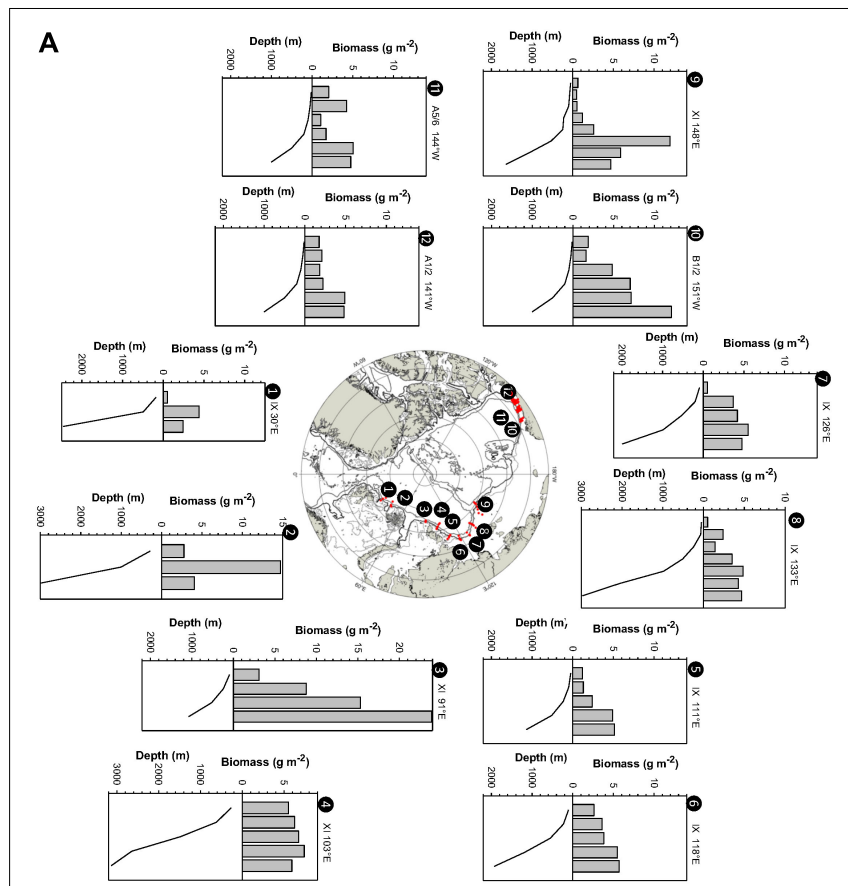

B

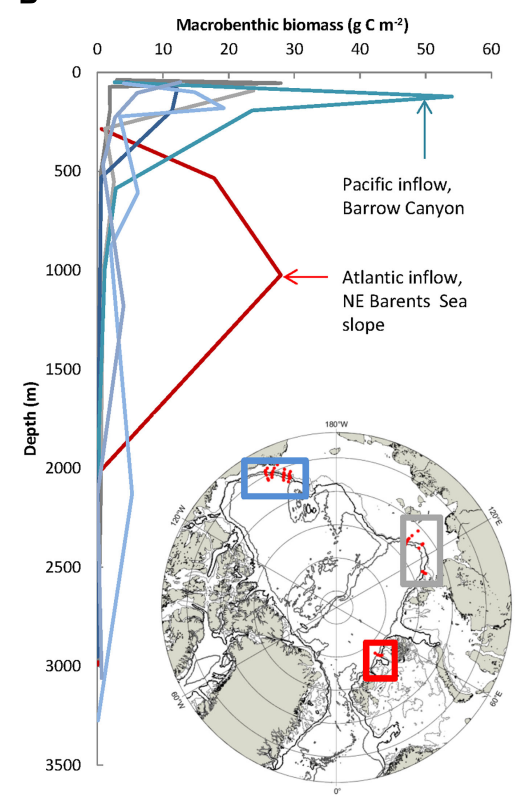

FIGURE 5 | Biomass distribution of biological components over slopes. (A) Vertically integrated dry weight biomass of mesozooplankton over slopes ( 20 to bottom depth of $\geq 1000 \mathrm{~m}$ ) at marked transects from shelf cross slope, showing enhanced biomass over slopes; data from multinet samples covering surface to near-bottom in discrete layers (single hauls from Kosobokova and Hirche, 2009, and averages of multiple hauls from Smoot and Hopcroft, 2017); isobaths show 200, 400, and 2000 m; not different data ranges along the vertical axes. (B) Macrobenthic biomass declining over shelf-cross-slope sections at marked transects, but with enhanced biomass near Pacific (blue lines/box) and Atlantic (red line/box) inflows. Gray lines/box: Laptev Sea; data are means of typically at least three replicates per location from $0.1 \mathrm{~m}^{2}$ van Veen grab samples from Grebmeier (2012) and $0.02 \mathrm{~m}^{2}$ box core samples from Vedenin et al. (2018); isobaths show 400 and $2000 \mathrm{~m}$. Transect numbers do not match those in Figures 1, 2 integrated biomass levels from surface to near-bottom increase from 1 to $7 \mathrm{~g}$ dry weigh (DW) $\mathrm{m}^{-2}$ near the shelf-break to $5-15 \mathrm{~g} \mathrm{DW} \mathrm{m}^{-2}$ over the slope (Figure $5 \mathrm{~A}$ ). Vertically, zooplankton concentrations are highest in the 50-200 m layer (Kosobokova and Hirche, 2009), suggesting the higher values over the slope are not merely a bias of integration depth. In the along-slope direction biomass is highest near sub-Arctic inflows, in particular close to the core of the Atlantic inflow (Kosobokova and Hirche, 2009; Kosobokova, 2012; Basedow et al., 2018). This biomass dense area (peak measured at $24 \mathrm{~g} \mathrm{DW}$ $\mathrm{m}^{-2}$ NE of Severnaya Zemlya; Kosobokova and Hirche, 2009) is dominated by the expatriate copepod Calanus finmarchicus which, after its injection north of Svalbard, is transported alongslope far into the slope areas of the interior Siberian shelves (Kosobokova and Hirche, 2009; Kosobokova, 2012; Wassmann et al., 2015). Similarly, zooplankton biomass in surface layers in the western part of the Beaufort Sea slope is enriched by Pacific zooplankton inputs at the Pacific inflow (Berline et al., 2008; Smoot and Hopcroft, 2017). Here, copepods in the genus Neocalanus in particular contribute advected biomass that is highest in the upper portion (200-500 m) of the Atlantic Layer (Smoot and Hopcroft, 2017) where biomass levels are comparable to the slope in the Atlantic inflow (Figure 5A). Within the western Beaufort Sea, biomass of these Pacific species declines moving eastward.

Benthic and demersal fish biomass generally declines with depth across the slopes towards abyssal plains. This trend applies to all size fractions including macroinfauna $(\geq 0.5$ or $1 \mathrm{~mm}$, inside sediment; Figure 5B) (Wlodarska-Kowalczuk et al., 2004; Bluhm et al., 2011; Grebmeier, 2012; Grebmeier et al., 2015; Vedenin et al., 2018), mega-epifauna (benthos in trawls or on photographs) (Ravelo et al., 2020, Jørgensen et al., unpubl. data), and demersal fish (Majewski et al., 2017; Norcross et al., 2017), with a less pronounced decrease for the smaller meiofauna ( $\geq 32 \mu \mathrm{m}-0.5$ or $1 \mathrm{~mm}$; Vanreusel et al., 2000; Wei et al., 2010). The underlying reason for benthic biomass declines with depth is primarily the diminishing vertical flux of particulate organic matter (i.e., food particles) with increasing depth (Wiedmann et al., 2020, and references therein). Macrofaunal biomass drops off from peaks of 10-20 $\mathrm{g} \mathrm{C} \mathrm{m}^{-2}$ on inflow shelves (Grebmeier, 2012), and $<1 \mathrm{~g} \mathrm{C} \mathrm{m}^{-2}$ on the interior Laptev Sea shelf (Vedenin et al., 2018), to an average $\sim 0.5 \mathrm{~g} \mathrm{C} \mathrm{m}^{-2}$ at the upper slope and $<0.2 \mathrm{~g} \mathrm{C} \mathrm{m}^{-2}$ at the lower slope (Wlodarska-Kowalczuk et al., 2004; Bluhm et al., 2005, 2011; Grebmeier et al., 2006; Nelson et al., 2014; Vedenin et al., 2018; estimated from replicate van Veen grab or box core samples at discrete sampling depths). Gross estimates of wet weight (WW) biomass of epibenthic and demersal fish at the Amerasian slope decrease from 2 to $20 \mathrm{~kg}$ WW $1000 \mathrm{~m}^{-2}$ at the outer shelf to generally $<5 \mathrm{~kg} \mathrm{WW}$ $1000 \mathrm{~m}^{-2}$ at $1000 \mathrm{~m}$, with fish biomass contributing generally $<15 \%$ to total biomass (Norcross et al., 2017; Ravelo et al., 2020; estimated from trawl hauls at discrete depths). In slope areas near advective inflows from the Atlantic and Pacific, however, the down-slope profile in biomass exhibits a peak at the depth of the shelf break where benthic biomass can be enhanced (Figure 5B). In the PW inflow specifically, macrobenthic biomass is clearly elevated at the head of Barrow Canyon (Grebmeier, 2012), and 
a tongue of elevated biomass tracks the outflowing nutrient and particle-rich PW along the upper slope of the western Beaufort Sea to roughly $150^{\circ} \mathrm{W}$ (Bilyard and Carey, 1979; Dunton et al., 2005; Ravelo et al., 2015). The active fishery on the deep-water shrimp Pandalus borealis at the upper slope north of Svalbard (Misund et al., 2016; Haug et al., 2017) gives testimony of enhanced biomass at the Atlantic inflow slope area as well, although exactly comparable numbers are yet unpublished.

\section{Higher Trophic Level Biomass and Distribution}

For the most abundant Arctic fish, Boreogadus saida (Polar cod in European and Arctic cod in North American nomenclature), biomass of certain age classes also appears to be elevated along the upper Arctic slopes. This pattern is, however, so far only confirmed for the Amerasian slopes (Crawford et al., 2012; Geoffroy et al., 2015; Majewski et al., 2016; Logerwell et al., 2018) where biomass levels are higher in the western Beaufort than farther east; it remains unclear if this "cod belt" is a panArctic phenomenon. In the along-slope direction, distribution patterns of (pelagic) B. saida larvae and juveniles were highest over slope areas in the central Kara, the Laptev and East Siberian seas as well as seasonally in the eastern Beaufort Sea (Suzuki et al., 2015; Mishin et al., 2018), while they were more abundant at the coast in the Barents and southwestern Kara Seas. Peaks in older B. saida biomass are documented for the mouths of Barrow and Mackenzie canyons, but with occurrence generally all along the slope of the Beaufort Sea (Crawford et al., 2012; Logerwell et al., 2018). Evidence for B. saida concentrations west of the Canadian Arctic Archipelago into McClintock Channel could be suspected based on observations of belugas echolocating for prey in the AW layer in that region (Carmack pers. obs.). In the vertical direction, the band of enhanced polar cod biomass in the Beaufort Sea is located where the relatively warm PSW and upper Atlantic Layer encroach the bottom along the continental slope (Parker-Stetter et al., 2011; Crawford et al., 2012; Majewski et al., 2016). This peak, reaching estimates of $>150,000$ individuals hectare ${ }^{-1}$ (August; Parker-Stetter et al., 2011), is in part driven by the vertical segregation of age classes with large, adult fish aggregating in those layers, albeit with some seasonal variations (Geoffroy et al., 2015). Peak densities and/or biomass coincided with waters above $0^{\circ} \mathrm{C}$ (Crawford et al., 2012; Majewski et al., 2016), suggesting a possible role of this comparatively warm upper slope habitat from a thermal optimum perspective (Drost et al., 2014), in conjunction with zooplankton prey concentrations. On the Eurasian inflow slope, no comparable concentrations of B. saida have been reported, but several observations perhaps indirectly point to concentrations of $B$. saida abundance over Eurasian slopes: First, a mesopelagic layer encountering the seafloor at upper slope depths contains large zooplankton and a variety of fish species (250-600 m, Knutsen et al., 2017) including and seasonally dominated by - B. saida (Geoffroy et al., 2019). And second, young Greenland halibut follow the continental slope and concentrate in the warmer $\left(-0.6\right.$ to $\left.1.2^{\circ} \mathrm{C}\right)$ water layer between $\sim 400$ and $780 \mathrm{~m}$ in St Anna and Voronin Troughs, where they actively feed on polar cod as their dominant prey (Dolgov and Benzik, 2017).

Continental slopes and shelf breaks with their associated frontal zones attract high numbers of foraging seabirds in many high latitude oceanic regions (e.g., Ainley and Jacobs, 1981; Baird and Mormede, 2014). Examples from temperate and sub-Arctic regions include: little auks in the NE Atlantic (Follestad, 1990), Cassin's auklet Ptychoramphus aleuticus in NE Pacific (Bertram et al., 2017; Wilkinson et al., 2018), and northern fulmars Fulmarus glacialis and fork-tailed storm-petrels Oceanodroma furcata in the Bering Sea (Schneider, 1982). While in the Arctic the role of slopes for higher trophic levels has not yet been summarized, we find that seabird accumulations at shelf break and continental slope area have in fact been documented for several species at both the Eurasian and Amerasian slopes. This is particularly the case for the small yet enormously numerous planktivorous Arctic endemic little auk, Alle. Little auks in Svalbard preferably fed far from the colony north of Svalbard in the marginal ice zone; with highest bird densities found over the slope area (concluded from data by Jakubas et al., 2017). Further east in the Kara and Laptev Seas, breeding distribution of the little auk also showed that nesting colonies were disproportionately located on coasts proximal to the shelf break (concluded from data by Gavrilo et al., 2011). This observation was consistent with Amélineau et al. (2016) who clearly demonstrated that slope waters off East Greenland were selected as profitable foraging area by the little auk irrespective of sea ice conditions, although these birds had to commute some $100 \mathrm{~km}$ from their breeding colonies to these preferred feeding grounds at the slope. These little auk distributions are influenced by the availability of large, lipid-rich copepod prey (Jakubas et al., 2017 and references therein), which we show can be concentrated in these slope regions. Attraction to shelf break areas was also documented for Ross's gull Rodostethia rosea by Hjort et al. (1997), who - during their Arctic Ocean crossing - found maximum concentrations of this species in the area where the shelf break is cut by St. Anna Trough. In the same area, Nansen already found these gulls to be common and locally numerous in the summer of 1895 (Collett and Nansen, 1900). For ivory gulls, the postbreeding staging areas are restricted to the marginal ice zone (Gilg et al., 2010), yet these staging areas also largely coincide with the continental slope from north of Svalbard to the east of the Severnaya Zemlya Archipelago (data from Gilg et al., 2010; Gavrilo et al., 2011). Examples of seabird concentrations at the slope of the Pacific inflow have also been documented. Total seabird abundance of both sea surface feeding bird species (kittiwakes Rissa tridactyla, short-tailed shearwaters Ardenna tenuirostris and Arctic terns Sterna paradisaea) and diving species (thick-billed murre Uria lomvia, horned puffin Fratercula corniculata and auklets Aethia spp.) peaked at the mouth of Barrow Canyon and the adjacent upper slope of the Beaufort Sea (Kuletz et al., 2015, 2019; Moore and Kuletz, 2019). We pose that for some of these seabird species (e.g., the little auk) the shelf break might be potentially more important than sea ice distribution. This hypothesis draws attention to the slope area in the context of Arctic climate change, since topographically controlled and biologically important oceanographic features 
could be resilient even under conditions of a shrinking sea ice cover. To test this hypothesis, further studies of birds distribution patterns in slope areas are warranted.

Patterns in marine mammal distributions are largely consistent with the described patterns in bird observations at Arctic continental slopes. In the area of western Fram Strait and north off Svalbard bowhead whale and narwhal sightings were also associated with slope regions (Storrie et al., 2018; de Boer et al., 2019). Seasonally occurring whales such as blue whales were also seen at the shelf break (Falk-Petersen et al., 2015; Vacquié-Garcia et al., 2017) argue that shelf-break upwelling in that area (particular the part called Whaler's Bay) and associated dense occurrence of Calanus spp. copepods may have sustained the once high abundance of bowhead whales in that area. Similarly, extensive surveys for marine mammals along Amerasian Arctic slopes revealed several marine mammal hotspots associated with the continental slope of the Beaufort Sea and especially with canyon areas and strong oceanographic fronts (Moore et al., 2010; Okkonen et al., 2011; Moore and Kuletz, 2019). Specifically, hotspots for bowhead whales Balaena mysticetus, gray whales and beluga whales were located at the mouth of Barrow Canyon at the Chukchi Sea slope, or along the slope of the Beaufort Sea between Barrow Canyon and Mackenzie Canyon. For bowhead whales in particular, a shelfbreak front in the Barrow Canyon area, when present under certain conditions, is thought to enhance feeding conditions on zooplankton for those whales (Okkonen et al., 2011; Citta et al., 2015). Occurrence of beluga whale aggregations in the Beaufort slope region (Hauser et al., 2015; Stafford et al., 2018) has been linked to prey concentrations of $B$. saida and zooplankton also associated with local advection and upwelling processes (Hauser et al., 2018). All of these findings suggest that slope and canyon bathymetry is a functionally important feature for many higher trophic level species.

\section{Community Structure and Biodiversity Trends}

As with biomass, the composition of biological communities (i.e., the members of all populations of species in a given area) vary strongly in their composition in the vertical and cross-slope dimensions, and to a lesser extent along-slope, both in the global ocean (Buhl-Mortensen et al., 2012) and in the Arctic. In all biological compartments, slope communities differ markedly from those on the shelves. Around the Arctic Basin perimeter, a vertical zonation of clearly distinct communities is identifiable across trophic levels as water depth increases from the shelf break to basin depths, from zooplankton and pelagic fishes in the water column to benthos and demersal fishes at the seafloor. For zooplankton communities, this vertical structure is evident near the slope but then extends horizontally throughout the basins, with epi-, meso-, and bathypelagic communities being correlated with vertical water mass structure (Figure 6A; Kosobokova et al., 2011; Smoot and Hopcroft, 2017). In surface waters and into mesopelagic layers, the expatriate fraction of the community can be used to track the strength of influence of Atlantic (e.g., Oithona atlantica, Calanus finmarchicus, Meganyctiphanes norvegica) and
Pacific (e.g., Neocalanus spp., Metrida pacifica) water masses as they spread along the slope perimeter (Hirche and Kosobokova, 2007; Kosobokova and Hirche, 2009; Nelson et al., 2009, 2014; Kosobokova and Hopcroft, 2010; Wassmann et al., 2015).

Benthic invertebrate communities also shift in community structure vertically (Figure 6B), with vertical shifts inherently tied to cross-slope gradients at the seafloor. As with zooplankton, taxonomic shifts often occur to other species or families within the same class or phylum, rather than to entirely different organisms at the phylum or class level. Down-slope community shifts in infaunal macrobenthos below the halocline, for example, are documented through changes in dominant polychaete and bivalve species on both Amerasian slopes (Chukchi and western Beaufort Sea: Bilyard and Carey, 1979; Pirtle-Levy, 2006; Grebmeier, 2012; Nelson et al., 2014) and Eurasian slopes (west of Svalbard: Wlodarska-Kowalczuk et al., 2004, Laptev Sea and north of Svalbard: Vedenin et al., 2018; Table 1). Large single-celled foraminifera become biomass dominant downslope towards the basin (Bluhm et al., 2005; Grebmeier et al., 2006). Among the larger epibenthos, slope communities are characterized by deep-water echinoderms common to Eurasian and Amerasian slopes (Table 1, Beaufort Sea: Ravelo et al., 2020; north of Svalbard: Jørgensen et al., unpubl. data; Fram Strait: Soltwedel et al., 2009). North of Svalbard at the upper slope (here 400-800 m) commercially fished hyperbenthic deepwater shrimps occur in high densities on soft-bottom substrate. Suspension-feeding Geodia sponges dominate the interspersed hard-bottom (Jørgensen et al., 2020) reflective of the highflow environment of the boundary current in this area (see section "Physical Oceanography of Arctic Slopes"), and different suspension feeders extend to the mid-slope $(800-1500 \mathrm{~m})$. Suspension-feeders are also more prominent in the Barrow Canyon outflow than on adjacent slope regions coinciding with the high velocity of transport of particle-rich water required to sustain them (Grebmeier, 2012; Pisareva et al., 2015). Outside the immediate inflow regions, slope regions tend to have high proportions of deposit-feeding taxa (Iken et al., 2005; Bell et al., 2016) reflecting fine sediment organic carbon deposition on slopes from shelves. On the lower slope to the rise, various smaller sponges, sea anemones, crustaceans, and sea cucumbers are characteristic epifaunal taxa at both Eurasian and Amerasian slopes. Glacial dropstones reach slopes and adjacent basins alike and house higher diversity than the otherwise dominating soft sediments (Bergmann et al., 2011; Meyer et al., 2016; Zhulay et al., 2019).

Communities of demersal fish on the slopes also shift in taxonomic composition from the adjacent shelf areas on both Eurasian and Amerasian slopes with differences also between upper and lower slope communities. Characteristic for the upper slope are high contributions of polar cod, the snail fish Liparis tunicatus and various eelpout species on the Pacific inflow slope (Beaufort Sea slope, Rand and Logerwell, 2011; Majewski et al., 2017; Norcross et al., 2017). At the Atlantic inflow, larger fish species are characteristic of the upper slope, such as Greenland halibut Reinhardtius hippoglossoides, Atlantic cod Gadhus morhua and the redfish Sebastes mentella (Bergstad et al., 2018; Jørgensen et al., unpubl. data); in warm years these species 
A

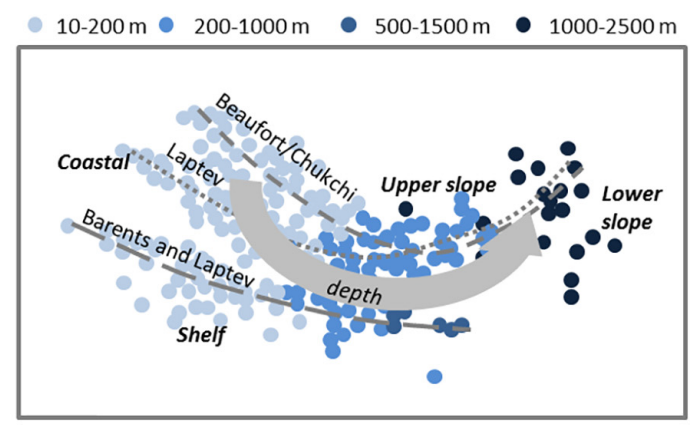

B
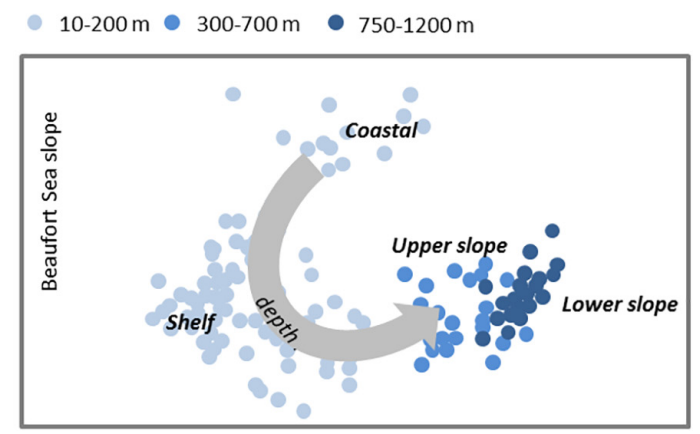

- 200-500m $\bullet 500-700 \mathrm{~m} \quad 800-1000 \mathrm{~m}$

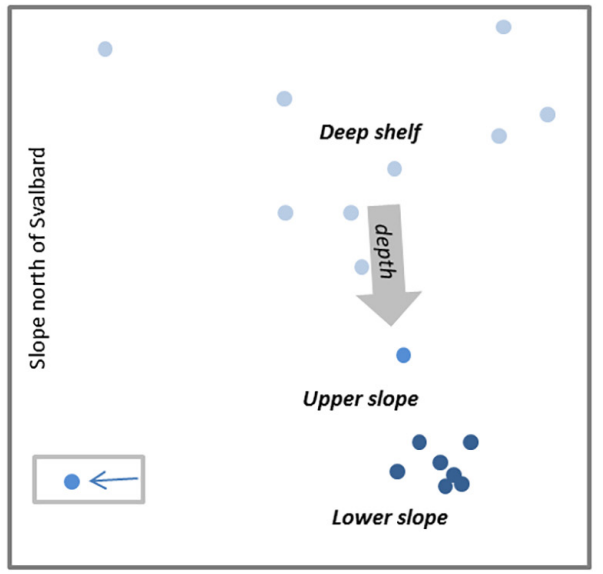

FIGURE 6 | Biological community structure for coast-to-basin transects for (A) meso-zooplankon (modified from Kosobokova et al., 2011) and (B) benthic epifauna (upper panel: modified from Ravelo et al., 2020, lower panel: Jørgensen et al., unpubl. data). Non-metric multidimensional scaling plots show community shifts for shelf (light blue), upper slope (mid blue), and (partial) lower slope. For meso-zooplankton each circle represents one discrete depth layer of a multinet haul overall covering surface to near-bottom depth; stippled lines denote three sampling expeditions for the most part representing the three indicated slope areas. For benthic epifauna, each circle represents a single demersal trawl haul for a shallower Amerasian shelf-slope transition (upper panel; beam trawl) and a deeper Eurasian shelf-slope transition (lower panel; Campelen shrimp trawl); trawl depth was limited to ca. $1000 \mathrm{~m}$.

even reach as far as the Kara Sea slope (Dolgov, 2013). On the mid to lower slope Arctic skate Amblyraja hyperborea, and the snail fish Liparis fabricii join Greenland halibut and the eelpouts, in both Atlantic and Pacific inflow areas (Beaufort
TABLE 1 | Example of benthic species characteristic for the slopes.

\begin{tabular}{ll}
\hline Example taxa at upper slope & Example taxa at lower slope \\
\hline Yoldiella lucida (ES) & Melinnopsis arctica \\
Thyasira dunbari (ES) & Galathowenia fragilis \\
Bathyaster vexillifer Ophiopleura & Aricidea spp. \\
borealis (AS, on shelf in Barents) & \\
Pontaster tenuispinus & \\
Zoantharia (AS) & Gorgonocephalus sp. (ES, on \\
& shelf in AB) \\
Geodia spp. (ES) & Umbellula encrinus \\
Sebastes mentella (ES) & Saduria sabini \\
Liparis spp. & Amblyraja hyperborea
\end{tabular}

Pandalus borealis (AS)

Reinhardtius hippoglossoides, various Zoarcidae including Lydodes spp.

Pacific affinity species are essentially absent. AS, taxa so far mentioned from Amerasian slopes; ES, taxa so far mentioned from Eurasian slopes.

Sea: Majewski et al., 2017; Barents Sea: Bergstad et al., 2018., Jørgensen et al., unpubl. data; Kara Sea: Dolgov, 2013). The major transition in fish species composition at the Atlantic inflow area north of Svalbard occurs between the slope $(>\sim 500 \mathrm{~m})$ and the upper slope/shelf break assemblages $(<500 \mathrm{~m})$ with more Arctic species in the deeper and more boreal species in the shallower community (Bergstad et al., 2018). A similar transition is equally distinct on the Amerasian slopes and interior Kara Sea slope, though it occurs shallower (matching the shallower shelf break $\sim 200 \mathrm{~m}$ ), with typical Arctic shelf taxa such as Myoxocephalus, Artediellus, and other sculpins, alligatorfish Aspidophoroides (formerly Ulcina) olrikki and related species disappearing at upper slope depths (Logerwell et al., 2011; Dolgov, 2013; Majewski et al., 2017; Norcross et al., 2017). Several fish species of the slopes extend into the basin (Stein et al., 2005; Zhulay et al., 2019), though few surveys have sampled beyond $1500 \mathrm{~m}$ due to logistical and time constraints. A difference between Amerasian and Eurasian slopes is that commercial densities of certain fish and shrimps reach the Eurasian inflow slope north of Svalbard.

Finally, biodiversity and biogeography patterns across some ecological groups also show distinct gradients from the shelf down the slope, which may have implications for potential dispersal trajectories of new and potentially invasive species entering the Arctic Ocean. Zooplankton biodiversity peaks beyond the shelf break and in vertical layers between 200 and $2000 \mathrm{~m}$ over slopes (and in the basins) (Kosobokova et al., 2011; Kosobokova, 2012; Smoot and Hopcroft, 2017; Ershova and Kosobokova, 2019). The lower slopes stand out in that endemic zooplankton species begin to be more numerous than on the shelves (Markhaseva, 1998; Markhaseva and Kosobokova, 1998; Andronov and Kosobokova, 2011; Kosobokova et al., 2011). As discussed above, expatriate zooplankton initially follow boundary currents, but then decline with increasing distance from the inflow source areas. For benthos, diversity may also be higher at the upper- and mid- slope than on adjacent shelves and basins (Wlodarska-Kowalczuk et al., 2004; Vedenin et al., 2018), and the fraction of endemic species increases at the lower slope (Bluhm et al., 2011; Mironov et al., 2013). Similarly, fish species richness 
is higher at the upper slope than adjacent shelf and slower slope in the Beaufort Sea (Majewski et al., 2017) and northern Kara Sea (Dolgov and Benzik, 2017). Biogeographically, the Arctic continental slope seafloor is primarily the domain of species of Atlantic-Arctic affinity, cosmopolitan deep-sea and - at the upper slope - amphiboreal species, while Pacific-Arctic species are largely absent in and below the Atlantic Layer, even on the Amerasian side (benthos: Bilyard and Carey, 1979; Krylova et al., 2013; Zhulay et al., 2019; Ravelo et al., 2020; fish: Dolgov, 2013; Mecklenburg et al., 2016).

\section{FUNCTIONS OF THE SLOPE: SYSTEM CONNECTIVITY VS. SEPARATION}

In this section we show that the geomorphological setting and physical processes reviewed in section "Physical Oceanography of Arctic Slopes" define the ecological functions that govern biological patterns described in section "Gradients in Biological Communities at Arctic Slopes." These functions are a consequence of the slope's role as both a connector and as a separator, in each of the three dimensions, along-slope, cross-slope and vertically (cf. Figure 1C).

\section{Connectivity}

\section{Along-Slope: Boundary Currents as Sub-Arctic Messenger}

Along-slope connectivity of energy, material properties and organism transport around the basin perimeter and partly into the basin interior is primarily mediated through the ACBC, and to a lesser extent through the various and highly variable Pacific inflow boundary currents. This "plumbing system" effectively enhances along-slope transport, a key functional feature affecting the Arctic Ocean's sea ice, climate and ecosystem structure at and far beyond the slope region (Wassmann et al., 2015). Given the way this flow is dynamically constrained to follow isobaths, it follows that the steeper the slope, the more tightly constrained and intense the transport (e.g., Polyakov, 2001; Aksenov et al., 2011). For example, the Laptev Sea is steeper, and the boundary current is hence more constrained than at, for example, the East Siberian Sea slope.

For ecosystem productivity, the boundary current system is a very effective conduit of sub-Arctic nutrients, detrital particles, and living phytoplankton, zooplankton and fish larvae (Nelson et al., 2009; Torres-Valdés et al., 2013; Gjøsæter et al., 2017; Knutsen et al., 2017; Hop et al., 2019). The species composition within this flow changes along-slope, with numbers of Atlantic/Pacific taxa decreasing and proportions of Arctic ones increasing. Given that the copepod Calanus finmarchicus is incapable of reproduction during its transit along-slope (Hirche and Kosobokova, 2007) biomass gradually diminishes through consumption and natural mortality (Wassmann et al., 2015). At the slope north of Svalbard, for example, its proportion is $\sim 40 \%$ while it drops to $5 \%$ or less at the New Siberian Islands (Kosobokova, 2012); low numbers of C. finmarchicus reach as far as the East Siberian Sea slope (Ershova et al., 2019). Estimates of the amount of biomass injected into the slopes at the inflows are on the order of 1.75 million tons of zooplankton DW year ${ }^{-1}$ $\left(\sim 0.8\right.$ million tons $\mathrm{C}$ year $\left.{ }^{-1}\right)$ in the Pacific inflow (Springer et al., 1996; Wassmann et al., 2015). Estimates for the Atlantic inflow were even higher than that $\left(0.5\right.$ million tons $\mathrm{C}$ year ${ }^{-1}$ for C. finmarchicus alone, Basedow et al., 2018, or 0.9 million tons $\mathrm{C}_{\text {year }}{ }^{-1}$ of $C$. finmarchicus and C. glacialis combined, from model estimates, Wassmann et al., 2015). It is the persistent through-flow of these zooplankters that ensures plentiful feeding opportunities for their predators (Wassmann et al., 2019).

Several factors contribute to variability and loss of material transport along the boundary current path and these pertain, one, to the water transport, and two, to the transport of its material load. Loss of water and biomass from the boundary current occurs at intersections with ocean ridges (e.g., the Lomonosov, Alpha-Mendeleev, and Northwind Ridges), through flow instabilities that eject water into the basin interior (e.g., eddies, intrusion), and through relaxed slope steepness (releasing the tightness of the flow). The combined effects of these contribute to the downstream weakening of the boundary current. For example, the intersection of the Lomonosov Ridge with the slope and reduced slope angle towards the Amerasian Basin serve to bifurcate the boundary current and send a fraction across the basin as part of the Trans-Polar Drift (Rudels et al., 1994; McLaughlin et al., 1996). Likewise, the complex topography of the Chukchi Borderland acts to bifurcate the boundary current into two branches, one flowing north and the other through a gap south of the Northwind Ridge. Similarly, the PW inflow and its material loads may be weakened or even reversed by the clockwise (i.e., counter-opposing) wind-driven Beaufort Gyre and plumes of slope-constrained PW may be lost to the Amerasian Basin interior (e.g., Shimada et al., 2006). The magnitude of pelagic biomass transport within the boundary current on in the Atlantic inflow is seasonally variable which is related to seasonally changing vertical distribution of these zooplankton rather than variations in water transport (Basedow et al., 2018). Model simulations suggest that variability is also possibly related to variation in upstream source regions of the zooplankton (Wassmann et al., 2019). In the Pacific inflow changes in water temperature associated with sea ice retreat correlate with zooplankton biomass in the boundary current at the Chukchi Sea slope, and into the Canada Basin (Itoh et al., unpubl. data). Grazing on the algal bloom, natural mortality, consumption of copepods by fish, seabirds and mammals and other trophic relationships all also contribute to reduced biomass transport in the boundary current as the distance from the inflow decreases.

\section{Cross-Slope "Leaks" Facilitate Connectivity}

Earlier we outlined that a number of cross-shelf processes manage to break through the barriers of the along-slope fronts. One of these is shelf-break upwelling, a globally common phenomenon (Kämpf and Chapman, 2016) where surface waters above the shelf are driven offshore by upwelling favorable winds - in the Arctic generally easterlies - or by ice drift, to be replaced by deeper waters overlying the slope that are drawn onshore (Figure 4C). In the Arctic setting, halocline and upper $\mathrm{AW}$ is moved upwards cross-slope onto the shelves, facilitated by the 
rapidly changing water depth above the slope during situations of upwelling-favorable wind (Carmack and Chapman, 2003; Cottier et al., 2007; Williams et al., 2008; Pickart et al., 2009, 2013a,b; Okkonen et al., 2009; Williams and Carmack, 2015; Randelhoff and Sundfjord, 2018). Convergence or divergence of isobaths along the slope can also result in locally intensified upwelling through acceleration or deceleration of isobath-following flows (Williams and Carmack, 2008). In particular, submarine canyoncutting slopes result in very sharp changes in the direction (curvature) of isobaths, and the dynamics of isobath-following flows and thus can intensify upwelling and downwelling across the shelf-slope boundary (Carmack and Kulikov, 1998; Williams et al., 2006; Williams and Carmack, 2008). Deeper shelves like the Barents Sea, in contrast, are less likely to experience upwelling (Randelhoff and Sundfjord, 2018). The topic has been a key research focus around the Arctic due to strong implications for heat budgets, nutrient transport and primary production (cf. Tremblay et al., 2014). Phytoplankton production is enhanced by upwelled nutrients in the Beaufort Sea (Tremblay et al., 2011, 2014) and such blooms are thought to boost grazing zooplankton biomass (Tremblay et al., 2011; Falk-Petersen et al., 2015) and benthic carbon demand (Tremblay et al., 2011). FalkPetersen et al. (2015) hypothesize that upwelling with subsequent zooplankton biomass increase could be partly related to high bowhead whale numbers during the whaling period on the northern Svalbard shelf break. The current literature suggests that the relative roles of advected vs. upwelled nutrients and particulate constituents shift along the slopes from a large role of the former at inflow slopes to a larger role of the latter at interior slopes.

Downwelling, in contrast, occurs when westerly winds over open water or drifting ice force surface waters above the shelf and slope onshore, thus drawing sub-surface shelf waters from offshore over the slope and into the basin (Sverdrup et al., 1942). Functions associated with downwelling are less well understood and draw less attention than those of upwelling. If sustained over a summer, ice-free period, downwelling may precondition winter conditions by forcing low salinity and nutrient poor waters onshore and constraining the seaward spreading of incoming river waters. If sustained over a sufficiently broad region, downwelling may thereby help the Riverine Coastal Domain (cf. Carmack et al., 2015) to remain intact along the coastline; thus, we hypothesize, supporting along-shore transport of material properties and coastal organisms including meroplankton and fish (cf. Griffiths et al., 1983; Craig, 1984; Fechhelm et al., 2007). Similar to upwelling, we suspect this process may be more prominent along narrow and shallow shelves.

In addition to wind-driven upwelling and downwelling, density-driven flows resulting from brine drainage during sea ice formation also provide a connection pathway between the shelves and the slope domain (Aagaard et al., 1981; Melling and Lewis, 1982; Schauer et al., 1997; Figure 4D). Not only do these waters provide important contributions to the halocline complex and potentially to the ventilation of the deep Arctic Ocean (Aagaard et al., 1985; Aagaard and Carmack, 1994; Rudels et al., 1994), but they also drive contour-following currents along the slope with the descending plume turning to the right by the Coriolis force
(Chapman and Gawarkiewicz, 1995). Dense water formation is particularly prominent in polynyas, sea ice formation factories that occur in all coastal regions around the Arctic (Ito et al., 2015) where heat flux and frazil ice formation are great (Figure 4D), and in shallow water where less dilution takes place. Densification of surface waters and subsequent sinking and off-shelf flow outside polynyas are episodic and difficult to observe, but also occur. Dense water production hotspots include the northeastern Kara Sea and northwestern Laptev Sea, where modeling studies (Ivanov and Golovin, 2007) discussed cascading of dense shelf waters down the continental slope to a depth of $\sim 400 \mathrm{~m}$. The depths to which these winter-formed dense waters can reach depend on plume entrainment rates, upper ocean salinity prior to freeze-up (i.e., preconditioning) and ice production rates, which are both quite high in that region. However, with their close proximity to the large Arctic rivers, surface waters are becoming increasingly fresher (Janout et al., 2020, this issue), and thus even strong ice formation rates may not sufficiently densify these shelf waters to flow far down the slope. Densification and drainage are especially complex near the numerous topographic features (submarine valleys, troughs, canyons) that are too deep to locally form dense water by brine convection, but which can collect dense water and serve as drainage pathways (Janout et al., 2017).

Physical processes facilitating downwelling (dense-water formation and wind) can transport organic and inorganic material to depth, thus enhancing the biological carbon pump in the shelf-break region. We suggest that fixed carbon and organic detritus, both in surface waters and in advected waters associated with the ACBC, can in fact exhibit enhanced export from surface and intermediate waters to the deep Arctic basin, where it can be sequestered for the long-term. Removal of fixed carbon, as well as dissolved $\mathrm{CO}_{2}$ by these physical processes should increase the air-sea gradient in inorganic carbon and lead to greater uptake of $\mathrm{CO}_{2}$ from the atmosphere. The relative importance of these processes and the inverse, where upwelling brings inorganic carbon and perhaps even organic material to the surface, has not been addressed on a basin-wide scale.

Organic and inorganic constituents are also transported cross-slope with transport pathways associated with turbidity plumes, eddies interacting with the seafloor, and internal waves (Fohrmann et al., 2001). This cross-slope transport is - on Arctic and global slopes - reflected in enhanced content of total organic carbon in the sediment associated with a higher percentage of silt and clay sediments as fine particles settle out on the slope regions (Grebmeier et al., 2006; Mathis et al., 2014). Depending on location around the basin perimeter, composition of organic matter delivered to slopes has differing proportions of marine vs. terrestrial sources, with higher terrestrial fractions in areas where river influence reaches the slope (Fahl and Stein, 1997), i.e., generally in interior slopes, thus affecting food quality for benthic consumers (Bell et al., 2016). For example, water from the Mackenzie River, the Arctic river with the highest load of terrestrial organic matter (Rachold et al., 2004), provides a carpet of presumed refractory material that reaches the Beaufort Sea slope (Magen et al., 2010; Bell et al., 2016). At inflow (upper) slopes, in contrast, marine-derived carbon has a larger role (Magen et al., 2010; Divine et al., 2015). That this material is 
efficiently incorporated into the food web is, for example, also indicated in enhanced biological oxygen consumption in the sediments of the upper slope in and near Barrow Canyon and reaching down-slope with even a small increase at depths just past 2000 m (Moran et al., 2005; Grebmeier et al., 2006; Grebmeier and Barry, 2007, their Figure 6). In addition to this carbon supply, internal waves can mobilize sediments (Fahrbach and Meincke, 1982), thereby contributing to structuring seafloor communities since they respond to grain size composition (Ravelo et al., 2015).

We note that not all forcing mechanisms have uni-directional outcomes, for example upwelling and downwelling winds act primarily in the cross-slope direction, but will also have an along-slope function by generating a transient, along-slope jet in the direction of the wind along the upper slope (Williams and Carmack, 2015; Figure 4C). This is because over the upper slope there is less water for the wind to accelerate than in deeper waters farther offshore, and so the acceleration is greater there, leading to faster flow (the transient jet). This effect is more pronounced for shallow shelf-breaks where there is less water to accelerate over the upper slope (Randelhoff and Sundfjord, 2018). Functionally, the formation of transient, shelf-break jets associated with upwelling and downwelling may transport biota, and winnow and re-suspend sediments along the upper slope (cf. Williams and Carmack, 2015), again with effects on benthic community composition given their substrate affinity.

\section{Vertical Connectivity at the Slope by Differential Weakening of Vertical Stratification}

In general, halocline stratification throughout the Arctic Basins strongly constrains the vertical exchange of heat, nutrients, oxygen, biogeochemical tracers and other properties (McLaughlin and Carmack, 2010; Nishino et al., 2019; Randelhoff et al., 2020). At the slopes, however, stronger currents infer greater vertical shear and thus stronger mixing between AW and the overlying halocline compared to adjacent basins, and this results in a relative weakening of vertical gradients of temperature and salinity at the slope (Polyakov et al., 2020). The rapidly decreasing intensity of horizontal currents with depth, i.e., strong vertical shear, is a robust feature of the pan-Arctic along-slope boundary current; examples include: northeast of Svalbard (Ivanov et al., 2009), St. Anna Trough (Dmitrenko et al., 2015), the eastern Eurasian Basin slope (Pnyushkov et al., 2018), and the Alaskan Arctic slope (Li et al., 2019). Moreover, baroclinic tides are amplified over steep topography (e.g., Rippeth et al., 2015; Luneva et al., 2015), and thus also contribute to strong vertical shear. Stronger vertical shear of mean and tidal currents over the Arctic slopes is one important contributor to enhanced mixing, for which the characteristic signature is reduced vertical stratification within the halocline and AW layers (Pnyushkov et al., 2018). Weakening of oceanic stratification in the halocline thus allows greater vertical transfer of AW heat and other scalar properties. These patterns of weakened temperature and salinity gradients represent proxies for exchange of nutrients and other biogeochemical variables through the halocline. For example, the progression of the boundary current eastward displays a cooling of the AW (section "Along-Slope: Boundary Currents") and a concurrent warming of the halocline, implying heat transfer upwards (Polyakov et al., 2010). We suggest that this process is accompanied by vertical flux of nutrients and other biogeochemical properties, and hence helps enhance levels of new production above the slope regions. These fluxes are not trivial to estimate given that uptake by phytoplankton, nitrification and horizontal advection may seasonally contribute to overall fluxes (Randelhoff et al., 2015). These authors argue, however, that the vertical nutrient flux component dominates during fall and winter when light levels limit phytoplankton growth, but that the relative roles of vertical and advective fluxes would vary along the Arctic slopes. They further suggest that this vertical nitrate replenishment in winter could potentially support increased production with decreasing sea ice in the inflow slopes in the future (also see section "Towards a Future Arctic Slope System”).

\section{Separation Generates and Maintains Structure}

\section{Fronts Provide Biological Concentration Mechanism Along and Cross-Slope}

Oceanic frontal zones are natural water mass boundaries often expressed by steeply sloping isolines of temperature and salinity; fronts are typically maintained by either divergent or convergent water movement. The Arctic fronts of interest here are (1) alongslope fronts created by the density structure associated with the ACBC, (2) cross-slope fronts occurring at sites of subduction of incoming sub-Arctic waters, or of lateral injection of subsurface waters at canyons (St. Anna Trough and Barrow Canyon), and (3) front associated with shelf-break jets, both surface and near-bottom. Due to the sustained intensity of the boundary current system these frontal zones are maintained and can act as an effective barrier between the abyssal ocean and shelves (Tverberg and Nøst, 2009). For example, analysis of 20132015 cross-slope mooring observations in the eastern European Basin revealed that currents, even in the very surface layer, are mostly aligned with the underlying topography throughout all averaging periods, regardless of wind direction (Baumann et al., 2018). Such fronts are found around the pan-Arctic slopes and appear to facilitate concentration of pelagic prey, as is also well-described for fronts globally (Pakhomov and McQuald, 1996; Genin, 2004; Trudnowska et al., 2016). As a result, horizontal property gradients establish hydrographic fronts that are observed along the AW pathway following the continental slope of the Eurasian Basin. The front at the eastern flank of the St. Anna Trough extends vertically throughout the entire water column with a strong horizontal density gradient (Dmitrenko et al., 2014) and is associated with bird concentrations (section "Gradients in Biological Communities at Arctic Slopes”). Similarly, Bauch et al. (2014) observed a front at the continental slope of the Laptev Sea separating shelf and basin waters, and hypothesized that the front is maintained by the ACBC. Also, a strong front near the shelf-break at the southern edge of Barrow Canyon is maintained under certain conditions and concentrates zooplankton which in turn attracts feeding groups of bowhead whales (Okkonen et al., 2011). Such zooplankton concentrations, explained through sharp density gradients (Prairie et al., 2012; Trudnowska et al., 2016), in 
turn explain the widespread aggregation of certain planktivorus seabirds and marine mammals (section "Gradients in Biological Communities at Arctic Slopes") at the Arctic inflow slopes.

\section{Light, Hydrography, and Depth Gradients Maintain Vertical Domains}

While vertical connectivity is enhanced over slopes compared to the basins (section "Vertical Connectivity at the Slope by Differential Weakening of Vertical Stratification") we briefly stress here that for the food web at slopes, vertical gradients in light, food supply and hydrographic properties remain strong, maintaining strong functional gradients in the vertical. The combined effects of primary productivity constrained to upper water, consumer biomass peaks in form of a 'lipid belt' of enhanced zooplankton and - regionally - polar cod, strong vertical flux attenuation prevalent anywhere in the global ocean, and the strong belts of boundary currents, the upper slope is clearly separated from the lower slope. Within it, the euphotic zone is distinct from the basins through enhanced mixing as shown in "Vertical Connectivity at the Slope by Differential Weakening of Vertical Stratification." Clearly separated, the lower slope is generally more characteristic of global deep-sea conditions in terms of low food supply, a community structure of more detrital and predatory taxa, and hydrographic stability. The described down-slope processes and possibly enhanced carbon pump, however, set this zone apart from the adjacent basin conditions.

\section{TOWARDS A FUTURE ARCTIC SLOPE SYSTEM}

In summary, we have shown that the Arctic continental slope is a distinct and dynamically active domain of the Arctic Ocean, manifest as narrow, horizontal bands with specific combinations of physical, chemical and biological properties that encircle the basin perimeter. Though spatially occupying only a small fraction $(\sim 6 \%)$ of the Arctic Ocean surface area, this domain exerts a disproportionately large influence on the overall functioning of Arctic Ocean ecosystems. Along-slope advective inputs from sub-Arctic seas create and maintain gradients, especially at the upper slope, in water mass and biotic properties moving along the basin perimeter in boundary currents that facilitate connectivity. The associated near-continuous carbon injections moving along-slope support multiple trophic levels in the water column (Wassmann et al., 2015), but also enhance food supply to the underlying seabed. The lower slope, in contrast, is a quiescent, low energy environment, less susceptible to climate forcing, and with comparatively low biological stocks and activity. Connectivity, both cross-slope and vertical, is generated by processes cutting through the boundary currents such as shelf break upwelling/ downwelling and brine drainage, particularly through canyons (Figures 4C,D). Transport of organic and inorganic matter is associated with these processes, providing a mechanism to enhance biological productivity subsequently attracting multiple trophic levels. Vertical connectivity also results from generally weaker stratification at the slopes than in the adjacent basins through shear and turbulent mixing, enhancing upward nutrient fluxes. At the same time, however, salt-stratification, light attenuation (determining the euphotic zone) and water depth (indirectly affecting vertical flux of organic matter) maintain distinct hydrographic layers, biological communities and production regimes. Water mass boundaries at fronts along-slope and cross-slope near canyons tend to be places where biological concentrations occur, often evident in predator-prey associations.

These factors contribute to the upper Arctic slope domain exhibiting signals of a changing climate rapidly and acutely because the upstream signals of change originating in sub-Arctic source waters and inflow shelves are rapidly propagated by the ACBC (Polyakov et al., 2020a, this issue). For example, the Arctic slope has warmed, as shown by an increase in the AW core temperature since 1980 (Figure 7). This trend, however, is not spatially uniform, as warming rates in the western Eurasian Basin $\left(0.03^{\circ} \mathrm{C}\right.$ per decade) exceed those in the Amerasian Basin $\left(0.01^{\circ} \mathrm{C}\right.$ per decade) by a factor of $2-3$, although along this track there has been little change of water transports over the past two decades (2003-2018; Pnyushkov, Polyakov et al., pers. com.). Freshening is also visible in the AW core over the slope regions of the Amerasian Basin while AW salinity over the Eurasian Basin slopes shows a uniformly increasing trend (Figure 7), consistent with the ongoing Atlantification of that part of the Arctic Ocean (e.g., Polyakov et al., 2017, 2018). Polyakov et al. (2020a, this issue) also documented that the halocline in both the Eurasian and Amerasian basins has shown a clear warming tendency, while salinity trends differ, increasing in the Eurasian Basin whereas the Amerasian Basin halocline has become increasingly fresher. Thus, the two basins and their slopes are structurally responding in opposite directions, reflected in weakening halocline stratification over the Eurasian Basin slope and strengthening over the Amerasian Basin slope areas. As a result, more favorable conditions are now established for higher biological productivity at the Eurasian Basin's margin while at the same time, conditions at the upper slope in the Amerasian Basin experiences increased constraints to vertical mixing and the flux of nutrients to the surface layer. The increased influx of warmer PW through Bering Strait since the early 1990s (Woodgate et al., 2006; Woodgate, 2018) implies enhanced along-slope PW transports of nutrients, pelagic biomass and propagules of benthic biota in the Amerasian Basin. There is, however, no direct observational evidence for this intensification above the slope. Benthic indicator species are, in fact, now actually distributed less far to the east than previously (Ravelo et al., 2015) which these authors suggested could be related to prolonged reversals of water flow from east to west reported by von Appen and Pickart (2012). Instead, sea-ice retreat in summer and stronger air-sea coupling may be detaching a greater fraction of this water from the shelfbreak current into the basin interior (Shimada et al., 2006).

Sea ice decline, in particular, has acted to accelerate the previously existing processes of shelf-slope exchange, including shelf-break upwelling and downwelling (Carmack and Chapman, 2003), cross-slope flow of brine-enriched dense water (Janout et al., 2017), and downslope transport of organic matter (Fahl and Stein, 1997). Now, the seasonal ice edge retreats well 

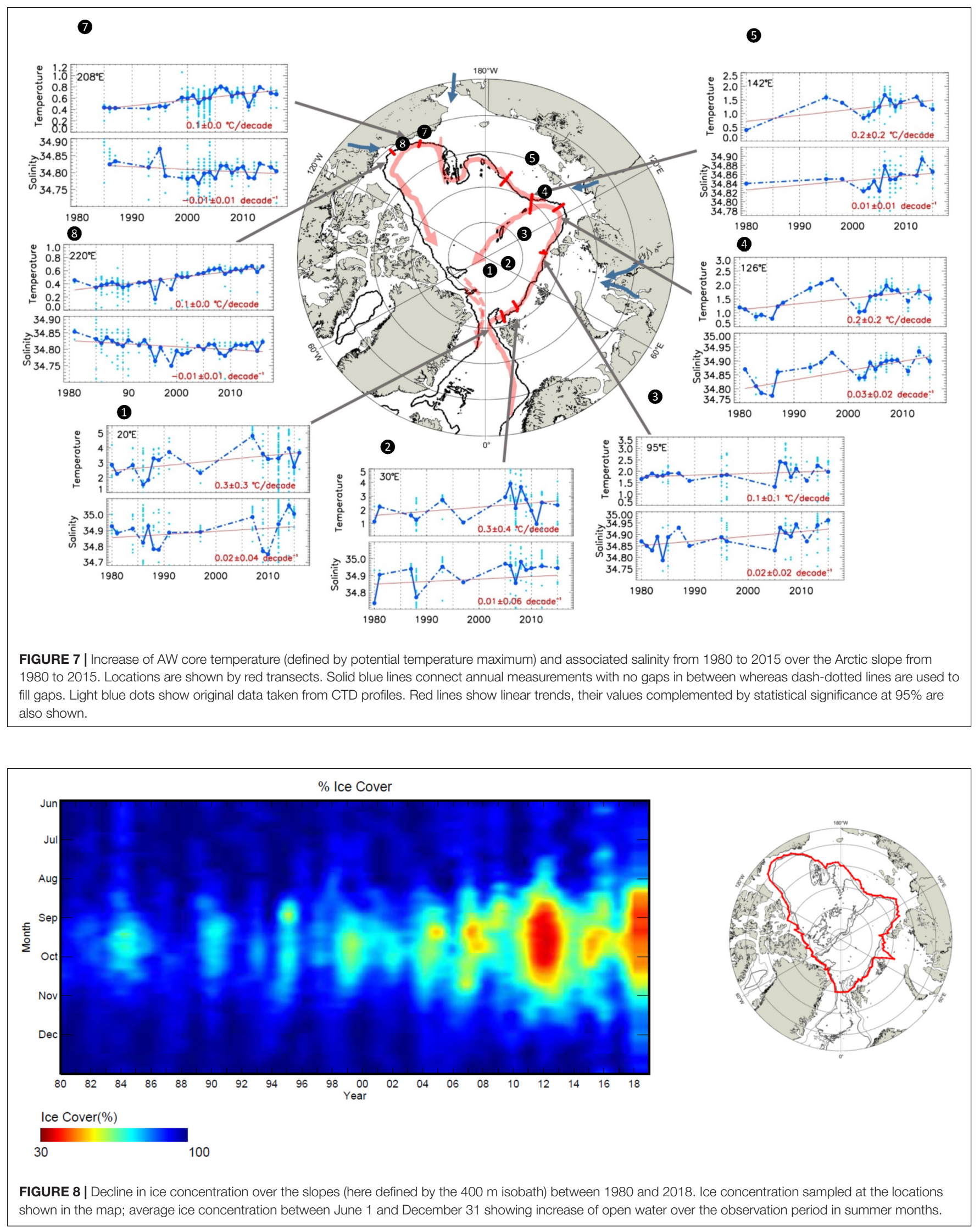
beyond the slopes into the basin in many regions (Figure 8), whereas only a few decades ago, seasonally ice-free waters were limited to near-shore regions along the periphery (Stroeve et al., 2012; Kwok et al., 2019). The decline in ice cover exposes waters and drifting ice above the slope to enhanced wind and radiative forcing, and thus both upwelling and downwelling favorable winds can now drive increased cross-slope exchange. This trend of increased exchange has demonstrated the potential to increase the flux of nutrient-rich, sub-Arctic Atlantic and Pacific waters onto the shelf, and potentially increase primary production (Tremblay et al., 2011; Spall et al., 2014).

Multiple processes were mentioned that may increase primary production over the slopes. To evaluate such potential changes on the pan-Arctic scale, we used the regional coupled physical and biological SINMOD system, run with atmospheric forcing data from the global MPI-ESM model system (Notz et al., 2013). Except for this forcing, the configuration is otherwise similar as presented in Slagstad et al. (2015). To eliminate interannual variability, the change is calculated by subtracting the decadal mean annual primary production over the period from 2090 to 2099 from the mean annual primary production over the period from 2006 to 2015. Simulated yearly primary production in the Arctic is particularly sensitive to how well the sea ice is represented by the ESM (Slagstad et al., 2011, 2015) and therefore the future projection of new production depends on future projection of summer sea ice cover. An ensemble simulation of the IPCC RCP 8.5 scenario that predicts a sharp decline in ice cover in September after 2050s (Notz et al., 2013) alters primary production (Figure 9). The magnitude of the change in production will depend on the forcing scenario, but qualitatively the results are consistent whether we run with forcing from other

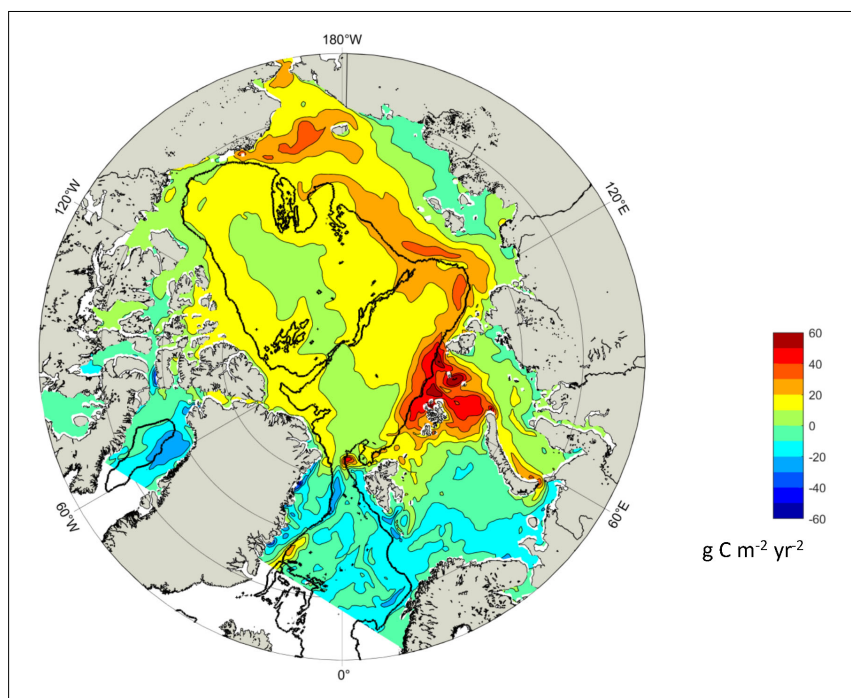

FIGURE 9 | Modeled change in annual primary production by the end of the century compared to the present climate based on SINMOD results for the RCP8.5 scenario. Predictions show peak increases (oranges and reds) partially coinciding with the continental slopes along the Atlantic inflow and Siberian slopes and enhanced production (yellow) over essentially the entire slope band.
EMSs or do more idealized blue Arctic scenarios (Slagstad et al., 2015). The results can be summarized in the Eurasian Arctic as an increase in new primary production in the northern Barents Sea and along the inflow path of AW north of the Barents Sea and further along the western Eurasian slope. Along the western Eurasian slope there is a projected increase of $20-40 \mathrm{~g} \mathrm{C} \mathrm{m}^{-2}$ year $^{-1}$ from today's values of $70-100 \mathrm{~g} \mathrm{C} \mathrm{m}^{-2}$ year $^{-1}$ with peaks in increase projected for the eastern Barents and western Kara seas. The Amerasian slope values are projected to increase by $10-$ $20 \mathrm{~g} \mathrm{C} \mathrm{m}^{-2}$ year $^{-2}$ from today's values of generally $<30 \mathrm{~g} \mathrm{C} \mathrm{m}^{-2}$ year $^{-1}$, with highest projected increase for the Laptev and East Siberian and lowest for parts of the Beaufort Sea slopes. With the projected change in ice conditions, the productive season will be longer though phytoplankton growth may eventually become nutrient limited. The strong stratification in parts of the Arctic constrains turbulence levels (Randelhoff et al., 2015), and future increases in new production will, therefore, depend on an increase in vertical fluxes of nutrients. SINMOD projects this to occur mainly in the northern Barents Sea and along the Siberian slopes due to weakening of the halocline and deeper mixing with underlying AW above the slope, a trend that is already taking place in these regions (Polyakov et al., 2017; Lind et al., 2018). These projected patterns are rather consistent with the patterns in documented increases in primary production and algal biomass in the last decade (Lewis et al., 2020), where these authors in fact suggest that regional influx of new nutrients played a role. Simulations also show a high projected increase in new production in the Chukchi Sea related to changes in ice conditions, a trend that again is in agreement with satellite based observations (Arrigo and van Dijken, 2015; Frey et al., 2019). Whether and to what extent this new production would reach the slopes and how that might relate to the increased volume transport of nutrient-rich water through Bering Strait from 0.7 to $1.2 \mathrm{~Sv}$ since the 1990s (Woodgate, 2018) warrants a thorough analysis.

Microbial and consumer communities above continental slopes are presented with changed proportions of carbon sources as well as temperature regimes. A new mix of carbon sources can be expected given the combination of the predicted increase in primary production, decrease in ice cover (and hence likely ice-algal production), potentially changed cross-slope transport of organic carbon delivered with sea ice, river run-off and permafrost (Holmes et al., 2002, 2012; Krumpen et al., 2019), and perhaps even macroalgal carbon reaching some slopes from nearby island groups with rocky shores. Overall, consumer responses are difficult to predict. Some changes would support increases in consumer production and biomass: increased pelagic primary production, upwelling, higher temperatures and associated enhanced survival and subsequent reproduction of advected zooplankton. In contrast, other changes might reduce production capacity, e.g., smothering by down-slope inorganic particles, increased metabolic demands related to temperature increase, and reduced food quality with increased fractions of terrestrial matter. In addition, the consumer communities at slopes themselves are beginning to change, at least near the subArctic inflows. Penetration of sub-Arctic Atlantic communities farther into the Arctic along-slope is documented for inflow 
shelves (e.g., Fossheim et al., 2015), and is now emerging also for at least individual surveyed species at the matching slopes. For example, recent studies found Greenland halibut Reinhardtius hippoglossoides to be distributed much further eastwards from the northern Barents Sea to the Kara Sea and Laptev Sea (Borkin et al., 2008; Sentyabov and Smirnov, 2010).

In conclusion, the distinct functions of the Arctic slope domain and the ongoing changes in this domain should be incorporated into future Arctic conceptual models and research planning. Based on the role of the slope in climate changes, both as an early warning network and as pathway of upstream change to the entire Arctic marine system, we recommend an interdisciplinary, international slope study be conducted in order to synoptically characterize connecting and separating processes over slopes. The developing international Synoptic Arctic Survey (SAS) for example, composed of regional shelfto-basin transects for multidisciplinary studies into the Arctic Basin and recommended interdecadal follow-up along timeseries lines (Paasche et al., 2019) can yield valuable pan-Arctic slope information on the status and change of the Arctic marine ecosystem also along slopes. Given the growing appreciation for the role of the numerous troughs and canyons, vertical and lateral physical and biological exchange and mixing mechanisms of AW with peripheral waters are crucial study subjects to understand the future of the Arctic ecosystem. Also, a suite of slope transects should monitor the potential arrival of invasive species or those expanding their current distribution range as is already seen along the Atlantic inflow slope.

\section{AUTHOR CONTRIBUTIONS}

$\mathrm{BB}$ and $\mathrm{EC}$ conceived the idea and drafted the initial draft of the manuscript. BB led the writing of sections "Introduction: Motivation and Definitions" and "Gradients in Biological Communities at Arctic Slopes." MJ led section "Physical Oceanography of Arctic Slopes." BB, EC, and IP led section "Functions of the Slope: System connectivity vs. Separation."

\section{REFERENCES}

Aagaard, K. (1984). "The beaufort undercurrent," in The Alaskan Beaufort Sea: Ecosystems and Environments, eds P. W. Barnes, D. M. Schell, and E. Reimnitz (San Diego, CA: Academic Press Inc), 4-71.

Aagaard, K. (1989). A synthesis of the Arctic Ocean circulation. Rapp. P.-V. Reun. Cons. Int. Explor. Mer. 188, 11-22.

Aagaard, K., and Carmack, E. C. (1994). "The Arctic Ocean and climate: a Perspective," in The Polar Oceans and Their Role in Shaping the Global Environment Geophysical Monograph Series, 85, eds O. M. Johannessen, R. D. Muench, and J. E. Overland (Washington, D.C: American Geophysical Union), 5-20. doi: 10.1029/GM085p0005

Aagaard, K., Coachman, L. K., and Carmack, E. (1981). On the halocline of the Arctic Ocean. Deep-Sea Res. 28A, 529-545. doi: 10.1016/0198-0149(81)90115-1

Aagaard, K., Swift, J. H., and Carmack, E. C. (1985). Thermohaline circulation in the Arctic Mediterranean Seas. J. Geophys. Res. 90, 4833-4846. doi: 10.1029/ JC090iC03p04833

Ainley, D. G., and Jacobs, S. S. (1981). Sea-bird affinities for ocean and ice boundaries in the Antarctic. Deep-Sea Res. Part A 28, 1173-1185. doi: 10.1016/ 0198-0149(81)90054-6
BB, IE, and EC led section "Towards a Future Arctic slope System." MJ made Figures 1A, 2 and (with EC) Figure 3, SD made Figure 1B, EC made Figures $1 \mathrm{C}$ and 4 , and $\mathrm{BB}$ made Figures 5B and 6B (with data contributions by JG, KI, and LJ). $\mathrm{RH}$ and KK made Figures 5A and 6A. RK made Figure 7, IP made Figure 8. IE made Figure 9. All authors contributed to writing and editing.

\section{FUNDING}

BB was supported by the Arctic SIZE, a project co-funded by UiT - The Arctic University of Norway and the Troms $\varnothing$ Research Foundation (project number $01 \mathrm{vm} / \mathrm{h} 15$ ). SD was supported by the North Pacific Research Board grants A9199a and A91-00a as part of the Arctic Integrated Ecosystem Research Program. JG was supported by the United States National Science Foundation Arctic Observing Network program (1204082, 1702456, and 1917469), and NOAA Arctic Research Program (CINAR 22309.02). The research of KK was performed in the framework of the state assignment of IO RAS (theme No. 0149- 2019-0011) and was partially supported by RFBR grant no 19-04-00955 and RSF grant no 19-17-00058. IP was supported by NSF grants AON-1203473, AON-1724523, and AON-1708427.

\section{ACKNOWLEDGMENTS}

We thank all participants and the organizer of the truly inspiring fourth Pan-Arctic Symposium (Motovun, Croatia, 2017) which initiated this work. We appreciate discussion in particular with M. Sejr (Aarhus University, Denmark), A. Vedenin (Shirshov Institute, Russia), and A. Boetius (Alfred Wegener Institute Germany). P. Kimber and D. Dissing are thanked for their graphical support.

Aksenov, Y., Ivanov, V. V., Nurser, A. J. G., Bacon, S., Polyakov, I. V., Coward, A. C., et al. (2011). The Arctic circumpolar boundary current. J. Geophys. Res. 116:C09017.

Aksenov, Y., Karcher, M., Proshutinsky, A., Gerdes, R., De Cuevas, B., Golubeva, E., et al. (2016). Arctic pathways of Pacific Water: Arctic Ocean model intercomparison experiments. J. Geophys. Res. Oceans 121, 27-59. doi: 10.1002/ 2015JC011299

Amélineau, F., Grémillet, D., Bonnet, D., Le Bot, T., and Fort, J. (2016). Where to forage in the absence of sea ice? Bathymetry as a key factor for an Arctic seabird. PLoS One 11:e0157764. doi: 10.1371/ journal.pone.0157764

Anderson, L. G., Björk, G., Holby, O., Jutterström, S., Magnus Mörth, C., O’Regan, M., et al. (2017). Shelf-Basin interaction along the East Siberian Sea. Ocean Sci. 13, 349-363. doi: 10.5194/os-13-349-2017

Andronov, V. N., and Kosobokova, K. N. (2011). New species of small, bathypelagic calanoid copepods from the Arctic Ocean: Brodskius arcticus sp. nov. (Tharybidae) and three new species of Pertsovius gen nov. (Discoidae). Zootaxa 2809, 33-46. doi: 10.11646/zootaxa.2809.1.3

Arrigo, K. R., and van Dijken, G. L. (2015). Continued increases in Arctic Ocean primary production. Prog. Oceanogr. 136, 60-70. doi: 10.1016/j.pocean.2015. 05.002 
Azzellino, A., Gaspari, S., Airoldi, S., and Nani, B. (2008). Habitat use and preferences of cetaceans along the continental slope and the adjacent pelagic waters in the western Ligurian Sea. Deep-Sea Res. I 55, 296-323. doi: 10.1016/j. dsr.2007.11.006

Baird, S. J., and Mormede, S. (2014). Assessing the Environmental Preferences of Seabirds and Spatial Distribution of Seabirds and Marine Mammals in the Southern Ocean Ross Sea region in late summer. New Zealand Aquatic Environment and Biodiversity Report No. 121. Available online at: https://fs. fish.govt.nz/Page.aspx?pk=113\&dk=24554 (accessed March 19, 2020).

Bareiss, J., and Görgen, K. (2005). Spatial and temporal variability of sea ice in the Laptev Sea: Analyses and review of satellite passive microwave data and model results, 1979 to 2002. Global Planet. Change 48, 28-54. doi: 10.1016/j.gloplacha. 2004.12.004

Basedow, S. L., Sundfjord, A., von Appen, W.-J., Halvorsen, E., Kwasniewski, S., and Reigstad, M. (2018). Seasonal variation in transport of zooplankton into the Arctic Basin through the Atlantic gateway, Fram Strait. Front. Mar. Sci. 5, 194. doi: 10.3389/fmars.2018.00194

Bauch, D., Torres-Valdes, S., Polyakov, I., Novikhin, A., Dmitrenko, I., McKay, J., et al. (2014). Halocline water modification and along-slope advection at the Laptev Sea continental margin. Ocean Sci. 10, 141-154. doi: 10.5194/os- 10-1412014

Baumann, T. M., Polyakov, I. V., Pnyushkov, A. V., Rember, R., Ivanov, V. V., Alkire, M. B., et al. (2018). On the seasonal cycles observed at the continental slope of the Eastern Eurasian Basin of the Arctic Ocean. J. Phys. Oceanogr. 48, 1451-1470. doi: 10.1175/JPO-D-17-0163.1

Bell, L. E., Iken, K., and Bluhm, B. A. (2016). The influence of terrestrial organic matter in marine food webs of the Beaufort Sea shelf and slope. Mar. Ecol. Prog. Ser. 550, 1-24. doi: 10.3354/meps 11725

Bergmann, M., Soltwedel, T., and Klages, M. (2011). The interannual variability of megafaunal assemblages in the Arctic deep sea: preliminary results from the HAUSGARTEN observatory $\left(79^{\circ} \mathrm{N}\right)$. Deep-Sea Res. I 58, 711-722. doi: 10.1016/j.dsr.2011.03.007

Bergstad, O. A., Johannesen, E., Høines, Å., Ellingsen, K. E., Lien, V. S., Byrkjedal, I., et al. (2018). Demersal fish assemblages in the boreo-Arctic shelf waters around Svalbard during the warm period 2007-2014. Polar Biol. 41, 125-142. doi: 10.1007/s00300-017-2176-2

Berline, L., Spitz, Y. H., Ashjian, C. J., Campbell, R. G., Maslowski, W., and Moore, S. E. (2008). Euphausiid transport in the western Arctic Ocean. Mar. Ecol. Prog. Ser. 360, 163-178. doi: 10.3354/meps07387

Bertram, D. B., Mackas, D. L., Welchd, D. W., Boyd, W., Rydera, J. L., Galbraithc, M., et al. (2017). Variation in zooplankton prey distribution determines marine foraging distributions of breeding Cassin's Auklet. Deep-Sea Res. I 129, 32-40. doi: 10.1016/j.dsr.2017.09.004

Bilyard, G. R., and Carey, A. G. (1979). Distribution of western Beaufort Sea polychaetous annelids. Mar. Biol. 54, 329-339. doi: 10.1007/BF00395439

Björk, G., and Winsor, P. (2006). The deep waters of the Eurasian Basin, Arctic Ocean: Geothermal heat flow, mixing and renewal. Deep-Sea Res. I 53, 1253 1271. doi: 10.1016/j.dsr.2006.05.006

Bluhm, B. A., Ambrose, W. G. Jr., Bergmann, M., Clough, L. M., Gebruk, A. V., Hasemann, C., et al. (2011). Diversity of the Arctic deep-sea benthos. Mar. Biodivers. 41, 87-107.

Bluhm, B. A., Kosobokova, K. N., and Carmack, E. C. (2015). A tale of two basins: an integrated physical and biological perspective of the deep Arctic Ocean. Prog. Oceanogr. 139, 89-121. doi: 10.1016/j.pocean.2015.07.011

Bluhm, B. A., MacDonald, I. R., Debenham, C., and Iken, K. (2005). Macro- and megabenthic communities in the high Arctic Canada Basin: initial findings. Polar Biol. 28, 218-231. doi: 10.1007/s00300-004-0675-4

Borkin, I. V., Vasil'ev, A. V., and Chetyrkina, O. Y. (2008). Ichthyofauna, in Ekosistema Karskogo morya (The Ecosystem of the Kara Sea). (Murmansk: Izd. PINRO), 130-206.

Brown, K. A., Holding, J. M., and Carmack, E. C. (2020). Understanding regional and seasonal variability is key to gaining a Pan-Arctic perspective on Arctic Ocean freshening. Front. Mar. Sci. 7:606. doi: 10.3389/fmars.2020. 00606

Buhl-Mortensen, L., Buhl-Mortensen, P., Dolan, M. F. J., Dannheim, J., Bellec, V., and Holte, B. (2012). Habitat complexity and bottom fauna composition at different scales on the continental shelf and slope of northern Norway. Hydrobiologia 685, 191-219. doi: 10.1007/s10750-011-0988-6
Cacchione, D. A., Pratson, L. F., and Ogston, A. S. (2002). The shaping of continental slopes by internal tides. Science 296, 724-727. doi: 10.1126/science. 1069803

Carmack, E., and Chapman, D. C. (2003). Wind-driven shelf/basin exchange on an Arctic shelf: the joint roles of ice cover extent and shelf-break bathymetry. Geophys. Res. Lett. 30:1778. doi: 10.1029/2003GL017526

Carmack, E., and Wassmann, P. (2006). Food webs and physical-biological coupling on pan-Arctic shelves: unifying concepts and comprehensive perspectives. Prog. Oceanogr. 71, 446-477. doi: 10.1016/j.pocean.2006.10.004

Carmack, E., Winsor, P., and Williams, W. (2015). The contiguous panarctic Riverine Coastal Domain: a unifying concept. Prog. Oceanogr. 139, 13-23. doi: 10.1016/j.pocean.2015.07.014

Carmack, E., Yamamoto-Kawai, M., Bacon, S., Bluhm, B., Haine, T., Lique, C., et al. (2016). Fresh water and its role in the Arctic Marine System: sources, disposition, storage, export, and physical and biogeochemical consequences in the Arctic and global oceans. J. Geophys. Res. 121, 675-717. doi: 10.1002/ 2015JG003140

Carmack, E. C., and Kulikov, E. A. (1998). Wind-forced upwelling and internal Kelvin wave generation in Mackenzie Canyon, Beaufort Sea. J. Geophys. Res. 103, 18447-18458. doi: 10.1029/98JC00113

Carmack, E. C., MacDonald, R. W., and Jasper, S. (2004). Phytoplankton productivity on the Canadian shelf of the Beaufort Sea. Mar. Ecol. Prog. Ser. 277, 37-50. doi: 10.3354/meps 277037

Chapman, D. C., and Gawarkiewicz, G. (1995). Offshore transport of dense shelf water in the presence of a submarine canyon. J. Geophys. Res. 100, 13,37313,387 .

Citta, J. J., Quakenbush, L. T., Okkonen, S. R., Druckenmiller, M. L., Maslowski, W., Clement-Kinney, J., et al. (2015). Ecological characteristics of core-use areas used by Bering-Chukchi-Beaufort (BCB) bowhead whales, 2006-2012. Prog. Oceanogr. 136, 201-222. doi: 10.1016/j.pocean.2014.08.012

Codispoti, L. A., Kelly, V., Thessen, A., Matrai, P., Suttles, S., Hill, V., et al. (2013). Synthesis of primary production in the Arctic Ocean: III. Nitrate and phosphate based estimates of net community production. Prog. Oceanogr. 110, 126-150. doi: $10.1016 /$ j.pocean.2012.11.006

Collett, R., and Nansen, F. (1900). "An account of the birds," in The Norwegian North Pole Expedition 1893-1896. Scientific Results, ed. F. Nansen (London: Longmans), 1-54. doi: 10.1111/j.1474-919x.1932.tb07605.x

Colloca, F., Carpentieri, P., Balestri, E., and Ardizzone, G. D. (2004). A critical habitat for Mediterranean fish resources: shelf-break areas with Leptometra phalangium (Echinodermata: Crinoidea). Mar. Biol. 145, 1129-1142. doi: 10. 1007/s00227-004-1405-8

Corlett, W. B., and Pickard, R. S. (2017). The Chukchi slope current. Prog. Oceanogr. 153, 50-56. doi: 10.1016/j.pocean.2017.04.005

Cottier, F. R., Nilsen, F., Inall, M. E., Gerland, S., Tverberg, V., and Svendsen, H. (2007). Wintertime warming of an Arctic shelf in response to large-scale atmospheric circulation. Geophys. Res. Lett. 34:L10607.

Craig, P. (1984). Fish use of coastal waters of the Alaskan Beaufort Sea. Am. Fish. Soc. 113, 265-282. doi: 10.1577/1548-8659(1984)113<265:fuocwo > 2.0.co;2

Crawford, R. E., Vagle, S., and Carmack, E. C. (2012). Water mass and bathymetric characteristics of Arctic cod habitat along the continental shelf and slope of the Beaufort and Chukchi seas. Polar Biol. 35, 179-190. doi: 10.1007/s00300-0111051-9

D’Asaro, E. A. (1988). Observations of small eddies in the Beaufort Sea. J. Geophys. Res. Oceans 93, 6669-6684. doi: 10.1029/jc093ic06p06669

de Boer, M. N., Janinhoff, N., Nijs, G., and Verdaat, H. (2019). Encouraging encounters: unusual aggregations of bowhead whales Balaena mysticetus in the western Fram Strait. Endangered Species Res. 39, 51-62. doi: 10.3354/esr00948

Divine, L. M., Iken, K., and Bluhm, B. A. (2015). Regional benthic food web structure on the Alaska Beaufort Sea shelf. Mar. Ecol. Prog. Ser. 531, 15-32. doi: 10.3354/meps 11340

Dmitrenko, I. A., Kirillov, S. A., Serra, N., Koldunov, N. V., Ivanov, V. V., Schauer, U., et al. (2014). Heat loss from the Atlantic water layer in the northern Kara Sea: causes and consequences. Ocean Sci. 10, 719-730. doi: 10.5194/os-10-7192014

Dmitrenko, I. A., Rudels, B., Kirillov, S. A., Aksenov, Y. O., Lien, V. S., Ivanov, V. V., et al. (2015). Atlantic Water flow into the Arctic Ocean through the St. Anna Trough in the northern Kara Sea. J. Geophys. Res. Oceans. 120, 5158-5178. doi: 10.1002/2015JC010804 
Dolgov, A. V. (2013). Annotated list of fish-like vertebrates and fish of the Kara Sea. J. Ichthyol. 53, 914-922. doi: 10.1134/s0032945213110039

Dolgov, A. V., and Benzik, A. N. (2017). Feeding of Greenland halibut Reinhardtius hippoglossoides (Pleuronectidae) in the Kara Sea. J. Ichthyol. 57, 402-409. doi: $10.1134 / \mathrm{s} 0032945217030043$

Drost, H. E., Carmack, E. C., and Farrell, A. P. (2014). Upper thermal limits of cardiac function for Arctic cod Boreogadus saida, a key food web fish species in the Arctic Ocean. J. Fish Biol. 84, 1781-1792. doi: 10.1111/jfb.12397

Dunton, K. H., Goodall, J. L., Schonberg, S. V., Grebmeier, J. M., and Maidment, D. R. (2005). Multi-decadal synthesis of benthic-pelagic coupling in the western arctic: role of cross-shelf advective processes. Deep-Sea Res. II 52, 3462-3477. doi: $10.1016 /$ j.dsr2.2005.09.007

Ershova, E., Descoteaux, R., Wangensteen, O., Iken, K., Hopcroft, R., Smoot, C., et al. (2019). Diversity and distribution of planktonic larvae in the Pacific Arctic and connectivity with adult benthic invertebrate communities. Front. Mar. Sci. 6:490. doi: $10.3389 /$ fmars.2019.00490

Ershova, E. A., and Kosobokova, K. N. (2019). Cross-shelf structure and distribution of mesozooplankton communities in the East-Siberian Sea and the adjacent Arctic Ocean. Polar Biol. 42, 1353-1367. doi: 10.1007/s00300-01902523-2

Fahl, K., and Stein, R. (1997). Modern organic carbon deposition in the Laptev Sea and the adjacent continental slope: surface water productivity vs. terrigenous input. Org. Geochem. 26, 379-390. doi: 10.1016/s0146-6380(97)00007-7

Fahrbach, E., and Meincke, J. (1982). High-frequency velocity fluctuations on a steep continental slope. Rap. P.-V. Reun. Int. Explor. Mer. 180, 76-77.

Falk-Petersen, S., Pavlov, V., Berge, J., Cottier, F., Kovacs, K. M., and Lydersen, C. (2015). At the rainbow's end: high productivity fueled by winter upwelling along an Arctic shelf. Polar Biol. 38, 5-11. doi: 10.1007/s00300-014-1482-1

Fechhelm, R. G., Streever, B., and Gallaway, B. J. (2007). The Arctic Cisco (Coregonus autumnalis) subsistence and commercial fisheries. Colville River, Alaska: a conceptual model. Arctic 60, 421-429.

Fofonof, N. P. (1956). Some properties of sea water influencing the formation of Antarctic Bottom Water. Deep-Sea Res. 4, 32-35. doi: 10.1016/0146-6313(56) 90029-6

Fohrmann, H., Backhaus, J. O., Blaume, F., Haupt, B. J., Kämpf, J., Michels, K., et al. (2001). "Modern ocean current-controlled sediment transport in the Greenland-Iceland-Norwegian (GIN) Seas," in The Northern North Atlantic: A Changing Environment, eds P. Schafer, W. Ritzrau, M. Schlüter, and J. Thiede (Berlin: Springer), 135-154. doi: 10.1007/978-3-642-56876-3_9

Follestad, A. (1990). The pelagic distribution of Little Auk Alle alle in relation to a frontal system off central Norway, March/April 1988. Polar Res. 8, 23-28. doi: 10.1111/j.1751-8369.1990.tb00371.x

Fossheim, M., Primicerio, R., Johannesen, E., Ingvaldsen, R. B., Aschan, M. M., and Dolgov, A. V. (2015). Recent warming leads to a rapid borealization of fish communities in the Arctic. Nat. Clim. Change 5, 673-677. doi: 10.1038/ nclimate2647

Frey, K. E., Comiso, J. C., Cooper, L. W., Grebmeier, J. M., and Stock, L. V. (2018). "Arctic Ocean primary productivity: the response of marine algae to climate warming and sea ice decline," in Arctic Report Card 2018, eds J. Richter-Menge, M. L. Druckenmiller, and M. Jeffries (Washington, DC: NOAA).

Frey, K. E., Comiso, J. C., Cooper, L. W., Grebmeier, J. M., and Stock, L. V. (2019). "Arctic Ocean primary productivity: the response of marine algae to climate warming and sea ice decline," in Arctic Report Card 2019, eds J. Richter-Menge, M. L. Druckenmiller, and M. Jeffries (Washington, DC: NOAA).

Gakkel, Y. Y. (1957). Continental slope as a geographical zone of the Arctic Ocean [In Russian]. Izv VGO 89, 493-507.

Gavrilo, M. V., Popov, A. V., and Spiridonov, V. A. (2011). "Sea ice biotopes and biodiversity hotspots in the Laptev Sea," in Atlas of Marine and Coastal Biological Diversities of the Russian Arctic seas eds V. Spiridonov, V. Gavrilo, N. Nikolaeva, and E. Krasnova (Moscow: WWF), 36-37.

Gawarkiewicz, G., and Chapman, D. C. (1995). A numerical study of dense water formation and transport on a shallow, sloping continental shelf. J. Geophys. Res. 100, 4489-4501. doi: 10.1029/94jc01742

Genin, A. (2004). Bio-physical coupling in the formation of zooplankton and fish aggregations over abrupt topographies. J. Mar. Syst. 50, 3-20. doi: 10.1016/j. jmarsys.2003.10.008

Geoffroy, M., Daase, M., Cusa, M., Darnis, G., Graeve, M., Santana Hernández, N., et al. (2019). Mesopelagic sound scattering layers of the high Arctic: seasonal variations in biomass, species assemblage, and trophic relationships. Front. Mar. Sci. 6:364. doi: 10.3389/fmars.2019.00364

Geoffroy, M., Majewski, A., LeBlanc, M., Gauthier, S., Walkusz, W., Reist, J. D., et al. (2015). Vertical segregation of age- 0 and age-1+ polar cod (Boreogadus saida) over the annual cycle in the Canadian Beaufort Sea. Polar Biol. 39, 1023-1037. doi: 10.1007/s00300-015-1811-z

Gilg, O., Strøm, H., Aebischer, A., Gavrilo, M. V., Volkov, A. E., Miljeteig, C., et al. (2010). Post-breeding movements of northeast Atlantic ivory gull Pagophila eburnea populations. J. Avian Biol. 41, 532-542. doi: 10.1111/j.1600-048x.2010. 05125.x

Gjøsæter, H., Wiebe, P. H., Knutsen, T., and Ingvaldsen, R. B. (2017). Evidence of diel vertical migration of mesopelagic sound-scattering organisms in the Arctic. Front. Mar. Sci. 4:332. doi: 10.3389/fmars.2017.00332

Grebmeier, J. M. (2012). Shifting patterns of life in the Pacific Arctic and Sub-Arctic seas. Annu. Rev. Mar. Sci. 4, 63-78. doi: 10.1146/annurev-marine-120710100926

Grebmeier, J. M., and Barry, J. P. (2007). "Benthic processes in polynyas," in Polynyas: Windows to the World Elsevier Oceanography Series, Vol. 74, eds W. O. Smith Jr. and D. G. Barber (Amsterdam: Elsevier), 363-390. doi: 10.1016/ s0422-9894(06)74011-9

Grebmeier, J. M., Bluhm, B. A., Cooper, L. W., Danielson, S., Arrigo, K., Blanchard, A. L., et al. (2015). Ecosystem characteristics and processes facilitating persistent macrobenthic biomass hotspots and associated benthivory in the Pacific Arctic. Prog. Oceanogr. 136, 92-114. doi: 10.1016/j.pocean.2015.05.006

Grebmeier, J. M., Cooper, L. W., Feder, H. M., and Sirenko, B. I. (2006). Ecosystem dynamics of the Pacific-influenced northern Bering and Chukchi seas in the Amerasian Arctic. Prog. Oceanogr. 71, 331-361. doi: 10.1016/j.pocean.2006. 10.001

Grebmeier, J. M., Harvey, H. R., and Stockwell, D. A. (2009). The Western Arctic Shelf-Basin Interactions (SBI) project, volume II. An overview. Deep-Sea Res. II 56, 1137-1143. doi: 10.1016/j.dsr2.2009.03.001

Grebmeier, J. M., and Harvey, R. (2005). The Western Arctic Shelf? Basin Interactions (SBI) project: An overview. Deep-Sea Res. II 52, 3109-3115. doi: 10.1016/j.dsr2.2005.10.004

Griffiths, B. J., Craig, P. C., Gazey, W. T., and Helmricks, J. W. (1983). An assessment of the Colville River delta stock of Arctic cisco: Migrants from Canada. Biol. Pap. Univ. Alaska 21, 4-23.

Hanzlick, D., and Aagaard, K. (1980). Freshwater and Atlantic Water in the Kara Sea. J. Geophys. Res. 85, 4937-4942. doi: 10.1029/jc085ic09p04937

Hattermann, T., Isachsen, P. E., von Appen, W., Albretsen, J., and Sundfjord, A. (2016). Eddy-driven recirculation of Atlantic water in Fram Strait. Geophys. Res. Lett. 43, 3406-3414. doi: 10.1002/2016GL068323

Haug, T., Bogstad, B., Chierici, M., Gjøsæter, H., Hallfredsson, E., Høines, Å. S. et al. (2017). Future harvest of living resources in the Arctic Ocean north of the Nordic and Barents Seas: a review of possibilities and constraints. Fish. Res. 188, 38-57. doi: 10.1016/j.fishres.2016.12.002

Hauser, D. D., Laidre, K. L., Parker-Stetter, S. L., Horne, J. K., Suydam, R. S., and Richard, P. R. (2015). Regional diving behavior of Pacific Arctic beluga whales Delphinapterus leucas and possible associations with prey. Mar. Ecol. Prog. Ser. 541, 245-264. doi: 10.3354/meps11530

Hauser, D. D., Laidre, K. L., and Stern, H. L. (2018). Vulnerability of Arctic marine mammals to vessel traffic in the increasingly ice-free Northwest Passage and Northern Sea Route. Proc. Nat. Acad. Sci. U.S.A. 115, 7617-7622. doi: 10.1073/ pnas. 1803543115

Håvik, L., Våge, K., Pickart, R. S., Harden, B., Appen, W. J. V., Jónsson, S., et al. (2017). Structure and variability of the shelfbreak East Greenland Current north of Denmark Strait. J. Phys. Oceanogr. 47, 2631-2646. doi: 10.1175/jpo-d-170062.1

Hay, W. W. (2016). "Continental slope," in Encyclopedia of Marine Geosciences, eds J. Harff, M. Meschede, S. Petersen, and J. Thiede (Berlin: Springer). doi: 10.1007/978-94-007-6644-0_156-3

Hendry, K. R., Huvenne, V. A., Robinson, L. F., Annett, A., Badger, M., Jacobel, A. W., et al. (2019). The biogeochemical impact of glacial meltwater from Southwest Greenland. Prog. Oceanogr. 176:102126. doi: 10.1016/j.pocean.2019. 102126

Hill, V., Ardyna, M., Lee, S. H., and Varela, D. E. (2018). Decadel trends in phytoplankton production in the Pacific Arctic Region from 1960 to 2012. Deep-Sea Res. II 152, 82-94. doi: 10.1016/j.dsr2.2016.12.015 
Hirche, H.-J., and Kosobokova, K. N. (2007). Distribution of Calanus finmarchicus in the northern North Atlantic and Arctic Ocean - expatriation and potential colonization. Deep-Sea Res. II 54, 2729-2747. doi: 10.1016/j.dsr2.2007.08.006

Hjort, C., Gudmundsson, G. A., and Elander, M. (1997). Ross's Gulls in the Central Arctic Ocean. Arctic 50, 289-292.

Holmes, R. M., McClelland, J. W., Peterson, B. J., Shiklomanov, I. A., Shiklomanov, A. I., Zhulidov, A. V., et al. (2002). A circumpolar perspective on fluvial sediment flux to the Arctic Ocean. Glob. Biogeochem. Cycles 16:1098. doi: 10. 1029/2001GB001849

Holmes, R. M., McClelland, J. W., Peterson, B. J., Tank, S. E., Bulygina, E., Eglinton, T. I., et al. (2012). Seasonal and annual fluxes of nutrients and organic matter from large rivers to the Arctic Ocean and surrounding seas. Estuaries Coasts 35, 369-382. doi: 10.1007/s12237-011-9386-6

Hop, H., Assmy, P., Wold, A., Sundjord, A., Daase, M., Duarte, P., et al. (2019). Pelagic ecosystem characteristics across the Atlantic Water Boundary Current from Rijpfjorden. Svalbard, to the Arctic Ocean during summer (2010-2014). Front. Mar. Sci. 6:181. doi: 10.3389/fmars.2019.00181

Huthnance, J. M. (1981). Waves and currents near the continental shelf edge. Prog. Oceanogr. 10, 193-226. doi: 10.1016/0079-6611(81)90004-5

Iken, K., Bluhm, B. A., and Gradinger, R. (2005). Food web structure in the high Arctic Canada Basin: evidence from $\delta^{13} \mathrm{C}$ and $\delta^{15} \mathrm{~N}$ analysis. Polar Biol. 28, 238-249.

Ito, M., Ohshima, K. I., Fukamachi, Y., Simizu, D., Iwamoto, K., Matsumura, Y., et al. (2015). Observations of supercooled water and frazil ice formation in an Arctic coastal polynya from moorings and satellite imagery. Ann. Glaciol. 56, 307-314.

Itoh, M., Nishino, S., Kawaguchi, Y., and Kikuchi, T. (2013). Barrow Canyon volume, heat, and freshwater fluxes revealed by long-term mooring observations between 2000 and 2008. J. Geophys. Res. Oceans 118, 4363-4379. doi: 10.1002 /jgrc. 20290

Ivanov, V. V., and Golovin, P. N. (2007). Observations and modeling of dense water cascading from the northwestern Laptev Sea shelf. J. Geophys. Res. 112:C09003. doi: 10.1029/2006JC003882

Ivanov, V. V., Polyakov, I. V., Dmitrenko, I. A., Hansen, E., Repina, I. A., Kirillov, S. S., et al. (2009). Seasonal oceanic variability off Svalbard in 2004-06. Deep-Sea Res. I 56, 1-14.

Jakobsson, M. (2002). Hypsometry and volume of the Arctic Ocean and its constituent seas. Geochem. Geophy. Geosy. 35, 1-18.

Jakobsson, M., Mayer, L., Coakley, B., Dowdeswell, J. A., Forbes, S., Fridman, B., et al. (2012). The international bathymetric chart of the Arctic Ocean (IBCAO) version 3.0. Geophys. Res. Lett. 39:L12609.

Jakubas, D., Wojczulanis-Jakubas, K., Iliszko, L. M., Strøm, H., and Stempniewicz, L. (2017). Habitat foraging niche of a High Arctic zooplanktivorous seabird in a changing environment. Sci. Rep. 7:16203. doi: 10.1038/s41598-01716589-7

Janout, M., Hölemann, J., Laukert, G., Smirnov, A., Krumpen, T., Bauch, D., et al. (2020). On the variability of stratification in the freshwater-influenced Laptev Sea region. Front. Mar. Sci. 7:543489. doi: 10.3389/fmars.2020.543489

Janout, M. A., Aksenov, J., Hölemann, J. A., Rabe, B., Schauer, U., Polyakov, I. V., et al. (2015). Kara Sea freshwater transport through Vilkitsky Strait: Variability, forcing, and further pathways toward the western Arctic Ocean from a model and observations. J. Geophys. Res. Oceans 120, 4925-4944. doi: 10.1002/2014JC010635

Janout, M. A., Hölemann, J., Timokhov, L., Gutjahr, O., and Heinemann, G. (2017). Circulation in the northwest Laptev Sea in the eastern Arctic Ocean: crossroads between Siberian River water, Atlantic water and polynya-formed dense water. J. Geophys. Res. Oceans 122, 6630-6647. doi: 10.1002/2017JC013159

Jørgensen, L. L., Bakke, G., and Hoel, A. H. (2020). Responding to global warming: new fisheries management measures in the Arctic. Prog. Oceanogr. 188:102423. doi: $10.1016 /$ j.pocean.2020.102423

Kämpf, J., and Chapman, P. (2016). Upwelling Systems of the World. Cham: Springer.

Knutsen, T., Wiebe, P. H., Gjøsæter, H., Ingvaldsen, R. B., and Lien, G. (2017). High latitude epipelagic and mesopelagic scattering layers - a reference for future Arctic ecosystem change. Front. Mar. Sci 4:334. doi: 10.3389/fmars.2017.00334

Kosobokova, K., Hanssen, H., Hirche, H.-J., and Knickmeier, K. (1998). Composition and distribution of zooplankton in the Laptev Sea and adjacent Nansen Basin during summer, 1993. Polar. Biol. 19, 63-76.

Kosobokova, K. N. (2012). Zooplankton of the Arctic Ocean: Community Structure, Ecology, Spatial Distribution. Moscow: GEOS.
Kosobokova, K. N., and Hirche, H.-J. (2009). Biomass of zooplankton in the eastern Arctic Ocean - A baseline study. Prog. Oceanogr. 82, 265-280.

Kosobokova, K. N., and Hopcroft, R. R. (2010). Diversity and vertical distribution of mesozooplankton in the Arctic's Canada Basin. Deep-Sea Res. II 57, 96-110. doi: 10.1016/j.dsr2.2009.08.009

Kosobokova, K. N., Hopcroft, R. R., and Hirche, H.-J. (2011). Patterns of zooplankton diversity through the depths of the Arctic's central basins. Mar. Biodivers. 41, 29-50. doi: 10.1007/s12526-010-0057-9

Krumpen, T., Belter, H. J., Boetius, A., Damm, E., Haas, C., Hendricks, S., et al. (2019). Arctic warming interrupts the Transpolar Drift and affects long-range transport of sea ice and ice-rafted matter. Sci. Rep. 9:5459.

Krylova, E., Ivanov, D., and Mironov, A. (2013). The ratio of species of Atlantic and Pacific origin in modern Arctic fauna of bivalve molluscs. Invertebr. Zool. $10,89-126$.

Kuletz, K. J., Cushing, D. A., Osnas, E. E., Labunski, E. A., and Gall, A. E. (2019). Representation of the Pacific Arctic seabird community within the Distributed Biological Observatory array, 2007-2015. Deep-Sea Res. II 162, 191-210.

Kuletz, K. J., Fergusonb, M. C., Hurley, B., Gall, A. E., Labunski, E. A., and Morgan, T. C. (2015). Seasonal Spatial Patterns in Seabird and Marine Mammal Distribution in the Eastern Chukchi and Western Beaufort Seas: Identifying Biologically Important Pelagic Areas. Prog. Oceanogr. 136, 175-200.

Kwok, R., Markus, T., Kurtz, N. T., Petty, A. A., Neumann, T. A., Farrell, S. L., et al. (2019). Surface height and sea ice freeboard of the Arctic Ocean from ICESat-2: Characteristics and early results. J. Geophys. Res. Oceans 124, 6942-6959.

Kwok, R., Spreen, G., and Pang, S. (2013). Arctic sea ice circulation and drift speed: Decadal trends and ocean currents. J. Geophys. Res. Oceans 118, 2408-2425. doi: 10.1002/jgrc.20191

Levin, L. A., and Dayton, P. K. (2009). Ecological theory and continental margins: where shallow meets deep. Trends Ecol. Evol. 24, 606-617.

Lewis, K. M., van Dijken, G. L., and Arrigo, K. R. (2020). Changes in phytoplankton concentration now drive increased Arctic Ocean primary production. Science 369, 198-202.

Li, M., Pickart, R. S., Spall, M. A., Weingarner, T. J., Lin, P., Moore, G. W. K., et al. (2019). Circulation of the Chukchi Sea shelfbreak and slope from moored time series. Prog. Oceanogr. 172, 14-33.

Lind, S., Ingvaldsen, R. B., and Furevik, T. (2018). Arctic warming hotspot in the northern Barents Sea linked to declining sea-ice import. Nat. Clim. Change 8, 634-639.

Logerwell, E., Rand, K., Danielson, S., and Sousa, L. (2018). Environmental drivers of benthic fish distribution in and around Barrow Canyon in the northeastern Chukchi Sea and western Beaufort Sea. Deep-Sea Res. II 152, 170-181.

Logerwell, E., Rand, K., and Weingartner, T. J. (2011). Oceanographic characteristics of the habitat of benthic fish and invertebrates in the Beaufort Sea. Polar Biol. 34, 1783-1796. doi: 10.1007/s00300-011-1028-8

Luneva, M. V., Aksenov, Y., Harle, J. D., and Holt, J. T. (2015). The effects of tides on the water mass mixing and sea ice in the Arctic Ocean. J. Geophys. Res. Oceans 120, 6669-6699. doi: 10.1002/2014JC010310

Magen, C., Chaillou, G., Crowe, S. A., Mucci, A., Sundby, B., Gao, A., et al. (2010). Origin and fate of particulate organic matter in the southern Beaufort Sea-Amundsen Gulf region, Canadian Arctic. Estuar. Coast. Shelf Sci. 86, $31-41$.

Majewski, A. R., Atchison, S., MacPhee, S., Eert, J., Niemi, A., Michel, C., et al. (2017). Marine fish community structure and habitat associations on the Canadian Beaufort shelf and slope. Deep-Sea Res. I 121, 169-182. doi: 10.1016/ j.dsr.2017.01.009

Majewski, A. R., Walkusz, W., Lynn, B. R., Atchison, S., Eert, J., and Reist, J. D. (2016). Distribution and diet of demersal Arctic Cod, Boreogadus saida, in relation to habitat characteristics in the Canadian Beaufort Sea. Polar Biol. 39, 1087-1098.

Markhaseva, E. L. (1998). New species of the genus Xanthocalanus (Copepoda, Calanoida, Phaennidae) from the Laptev Sea. J. Mar. Syst. 15, 413-419.

Markhaseva, E. L., and Kosobokova, K. N. (1998). New and rare species of calanoid copepods from the central Arctic Basin (Crustacea, Copepoda). Zoosyst. Rossica 7, 45-53.

Martin, S., and Cavalieri, D. J. (1989). Contributions of the Siberian Shelf Polynyas to the Arctic Ocean. J. Geophys. Res. 94, 12725-12738. doi: 10.1029/ JC094iC09p12725

Mathis, J. T., Grebmeier, J. M., Hansell, D. A., Hopcroft, R. R., Kirchman, D. L., Lee, S. H., et al. (2014). "Carbon biogeochemistry of the Western Arctic: primary production, carbon expert and the controls on ocean acidification," in 
The Pacific Arctic Sector: Ecosystem Status and Trends in a Rapidly Changing Environment, eds J. M. Grebmeier and W. Maslowski (Dordrecht: Springer), 223-268.

Mathis, J. T., Pickart, R. S., Hansell, D. A., Kadko, D., and Bates, N. R. (2007). Eddy transport of organic carbon and nutrients from the Chukchi Shelf: impact on the upper halocline of the western Arctic Ocean. J. Geophys. Res. Oceans 112:C05011.

Matrai, P. A., Olson, E., Suttles, S., Hill, V., Codispoti, L. A., Light, B., et al. (2013). Synthesis of primary production in the Arctic Ocean: I. Surface waters, 1954-2007. Prog. Oceanogr. 110, 93-106. doi: 10.1016/j.pocean.2012.11.004

McLaughlin, F. A., and Carmack, E. C. (2010). Nutricline deepening in the Canada Basin, 2003-2009. Geophys. Res. Lett. 37:L24602. doi: 10.1029/2010GL045459

McLaughlin, F. A., Carmack, E. C., Macdonald, R. W., and Bishop, J. K. B. (1996). Physical and geochemical properties across the Atlantic/Pacific water mass front in the southern Canadian Basin. J. Geophys. Res. 101, 1183-1197. doi: 10.1029/95JC02634

Mecklenburg, C. W., Mecklenburg, T. A., Sheiko, B. A., and Steinke, D. (2016). Pacific Arctic Marine Fishes. Akureyri: Conservation of Arctic Flora and Fauna.

Melling, H., and Lewis, E. L. (1982). Shelf drainage flows in the Beaufort Sea and their effect on the Arctic Ocean pycnocline. Deep-Sea Res. I 29, 967-985.

Menze, S., Ingvaldsen, R. B., Haugan, P., Fer, I., Sundfjord, A., BeszczynskaMoeller, A., et al. (2019). Atlantic water pathways along the north-western Svalbard shelf mapped using vessel-mounted current profilers. J. Geophys. Res. Oceans 124, 1699-1716.

Meyer, K. S., Young, C. M., Sweetman, A. K., Taylor, J., Soltwedel, T., and Bergman, M. (2016). Rocky islands in a sea of mud: biotic and abiotic factors structuring deep-sea dropstone communities. Mar. Ecol. Prog. Ser. 556, 45-57.

Michel, C., Hamilton, J., Hansen, E., Barber, D., Reigstad, M., Iacozza, J., et al. (2015). Arctic Ocean outflow shelves in the changing Arctic: a review and perspectives. Prog. Oceanogr. 139, 66-88.

Mironov, A. N., Dilman, A. B., and Krylova, E. M. (2013). Global distribution pattern of genera occurring in the Arctic Ocean deeper than $2000 \mathrm{~m}$. Invertebr. Zool. 10, 167-194.

Mishin, A. V., Evseenko, S. A., Bol'shakov, D. V., and Bol'shakova, Y. Y. (2018). Ichthyoplankton of Russian Arctic Seas: 1. Polar cod Boreogadus saida. J. Ichthyol. 58, 710-716.

Misund, O. A., Heggland, K., Skogseth, R., Falck, E., Gjøsæter, H., Sundet, J., et al. (2016). Norwegian fisheries in the Svalbard zone since 1980. Regulations, profitability and warming waters affect landings. Polar Sci. 10, 312-322.

Moore, S. E., George, J. C., Sheffield, G., Bacon, J., and Ashjian, C. J. (2010). Bowhead whale distribution and feeding near Barrow, Alaska, in late summer 2005-06. Arctic 63, 195-205.

Moore, S. E., and Kuletz, K. J. (2019). Marine birds and mammals as ecosystem sentinels in and near Distributed Biological Observatory regions: an abbreviated review of published accounts and recommendations for integration to ocean observatories. Deep-Sea Res. II 162, 211-217.

Moran, S. B., Kelly, R. P., Hagstrom, K., Smith, J. N., Grebmeier, J. M., Cooper, L. W., et al. (2005). Seasonal changes in POC export flux in the Chukchi Sea and implications for water column-benthic coupling in Arctic shelves. Deep-Sea Res. II 52, 3427-3451.

Nash, J. D., Kunze, E., Toole, J. M., and Schmitt, R. W. (2004). Internal tide reflection and turbulent mixing on the continental slope. J. Phys. Oceanogr. 34, 1117-1134.

Nelson, J., Gradinger, R., Bluhm, B., Grebmeier, J. M., and Sirenko, B. (2014). "Lower trophics: Northern Bering, Chukchi, Beaufort (Canada and US) seas, and the Canada Basin," in The Pacific Arctic Sector: Ecosystem Status and Trends In a Rapidly Changing Environment, eds J. M. Grebmeier and W. Maslowski (Dordrecht: Springer), 269-336.

Nelson, R. J., Carmack, E. C., McLaughlin, F. A., and Cooper, G. A. (2009). Penetration of Pacific zooplankton into the western Arctic Ocean tracked with molecular population genetics. Mar. Ecol. Prog. Ser. 381, 129-138.

Nishino, S., Kawaguchi, Y., Inoue, J., Yamamoto-Kawai, M., Aoyama, M., Harada, N., et al. (2019). Do strong winds impact water mass, nutrient, and phytoplankton distributions in the ice-free Canada Basin in the fall? J. Geophys. Res. Oceans 125:e2019JC015428. doi: 10.1029/2019JC015428

Norcross, B., Apsens, S. J., Bell, L. E., Bluhm, B. A., Dissen, J. N., Edenfield, L. E., et al. (2017). US-Canada Transboundary Fish and Lower Trophic
Communities: Abundance, Distribution, Habitat and Community Analysis. BOEM Final Report Number 2017-034. (Washington, DC: BOEM), 463.

Notz, D., Haumann, F. A., Haak, H., Jungclaus, J. H., and Marotzke, J. (2013). Arctic sea-ice evolution as modeled by Max Planck Institute for meteorology's Earth system model. J. Adv. Model. Earth Syst. 5, 173-194. doi: 10.1002/jame.20016

Okkonen, S. R., Ashjian, C. J., Campbell, R. G., Clarke, J. T., Moore, S. E., and Taylor, K. D. (2011). Satellite observations of circulation features associated with a bowhead whale feeding 'hotspot' near Barrow, Alaska. Remote Sens. Environ. $115,2168-2174$.

Okkonen, S. R., Ashjian, C. J., Campbell, R. G., Maslowski, W., Clement-Kinney, J. L., and Potter, R. (2009). Intrusion of warm Bering/Chukchi waters onto the shelf in the western Beaufort Sea. J. Geophys. Res. Oceans 114:C00A11.

Paasche, O. A., Olsen, M., Arthun, L. G., Anderson, S.-A., Wangberg, C. J., Ashjian, J. M., et al. (2019). Addressing Arctic challenges requires a synoptic ocean survey. EOS 100. doi: 10.1029/2019EO136200

Pakhomov, E. A., and McQuald, C. D. (1996). Distribution of surface zooplankton and seabirds across the Southern Ocean. Polar Biol. 16, 271-286.

Parker-Stetter, S. L., Horne, J. K., and Weingartner, T. J. (2011). Distribution of polar cod and age-0 fish in the U.S. Beaufort Sea. Polar Biol. 43, 1543-1557. doi: 10.1007/s00300-011-1014-1

Pérez-Hernández, M. D., Pickart, R. S., Pavlov, V., Våge, K., Ingvaldsen, R. B., Sundfjord, A., et al. (2017). The Atlantic water boundary current north of Svalbard in late summer. J. Geophys. Res. Oceans 122, 2269-2290. doi: 10.1002/ 2016JC012486

Pickart, R. S., Moore, G. W. K., Mao, C., Bahr, F., Nobre, C., and Weingartner, T. J. (2016). Circulation of winter water on the Chukchi shelf in early summer. Deep-Sea Res. I Oceanogr. Res. Pap. 130, 56-75. doi: 10.1016/j.dsr2.2016. 05.001

Pickart, R. S., Moore, G. W. K., Torres, D. J., Fratantoni, P. S., Goldsmith, R. A., and Yang, J. (2009). Upwelling on the continental slope of the Alaskan Beaufort Sea: Storms, ice, and oceanographic response. J. Geophys. Res. 114:C00A13. doi: 10.1029/2008JC005009

Pickart, R. S., Pratt, L. J., Zimmermann, S., and Torres, D. J. (2005). Flow of wintertransformed water into the western Arctic. Deep-Sea Res. I Oceanogr. Res. Pap. 52, 3175-3198.

Pickart, R. S., Schulze, L. M., Moore, G. W. K., Charette, M. A., Arrigo, K. R., van Dijken, G., et al. (2013a). Long-term trends of upwelling and impacts on primary productivity in the Alaskan Beaufort Sea. Deep-Sea Res. I Oceanogr. Res. Pap. 79, 106-121.

Pickart, R. S., Spall, M. A., and Mathis, J. T. (2013b). Dynamics of upwelling in the Alaskan Beaufort Sea and associated shelf-basin fluxes. Deep-Sea Res. I Oceanogr. Res. Pap. 76, 35-51.

Pirtle-Levy, R. (2006). A Shelf-to-Basin Examination of Food Supply for Arctic Benthic Macrofauna and the Potential Biases of Sampling Methodology. Master's thesis, University of Tennessee, Knoxville, TN.

Pisareva, M. N., Pickart, R. S., Iken, K., Ershova, E. A., Grebmeier, J. M., Cooper, L. W., et al. (2015). The relationship between patterns of benthic fauna and zooplankton in the Chukchi Sea and physical forcing. Oceanography 28, 68-83. doi: 10.5670/oceanog.2015.58

Pnyushkov, A. V., Polyakov, I. V., Ivanov, V. V., Aksenov, Y., Coward, A. C., Janout, M., et al. (2015). Structure and variability of the boundary current in the Eurasian Basin of the Arctic Ocean. Deep-Sea Res. I Oceanogr. Res. Pap. 101, 80-97. doi: 10.1016/j.dsr.2015.03.001

Pnyushkov, A. V., Polyakov, I. V., Rember, R., Ivanov, V. V., Alkire, M. B., Ashik, I. M., et al. (2018). Heat, salt, and volume transports in the eastern Eurasian Basin of the Arctic Ocean from 2 years of mooring observations. Ocean Sci. 14, 1349-1371.

Polyakov, I. (2001). An eddy parameterization based on maximum entropy production with application to modeling of the Arctic Ocean circulation. J. Phys. Oceanogr. 31, 2255-2270.

Polyakov, I., Timokhov, L., Dmitrenko, I., Ivanov, V., Simmons, H., BeszczynskaMöller, A., et al. (2007). Observational program tracks Arctic Ocean transition to a warmer state. Eos Trans. Am. Geophys. Union 88, 398-399.

Polyakov, I. V., Alkire, M. B., Bluhm, B. A., Brown, K., Carmack, E. C., Chierici, M., et al. (2020a). Borealization of the Arctic Ocean in response to anomalous advection from sub-Arctic seas. Front. Mar. Sci. 7:491. doi: 10.3389/fmars.2020. 00491 
Polyakov, I. V., Pnyushkov, A. V., Alkire, M. B., Ashik, I. M., Baumann, T. M., Carmack, E. C., et al. (2017). Greater role for Atlantic inflows on sea-ice loss in the Eurasian Basin of the Arctic Ocean. Science 356, 285-291.

Polyakov, I. V., Pnyushkov, A. V., and Carmack, E. C. (2018). Stability of the arctic halocline: a new indicator of arctic climate change. Environ. Res. Lett. 13:125008.

Polyakov, I. V., Rippeth, T. P., Fer, I., Baumann, T. M., Carmack, E. C., Ivanov, V. V., et al. (2020b). Intensification of Near-Surface Currents and Shear in the Eastern Arctic Ocean. Geophys. Res. Lett. 46:e2020GL089469.

Polyakov, I. V., Timokhov, L. A., Alexeev, V. A., Bacon, S., Dmitrenko, I. A., Fortier, L., et al. (2010). Arctic Ocean warming reduces polar ice cap. J. Phys. Oceanogr. 40, 2743-2756. doi: 10.1175/2010JPO4339.1

Popova, E. E., Yool, A., Coward, A. C., Dupont, F., Deal, C., Elliott, S., et al. (2012). What controls primary production in the Arctic Ocean? Results from an intercomparison of five general circulation models with biogeochemistry. J. Geophys. Res. Oceans 117:C00D12. doi: 10.1029/2011jc007112

Prairie, J. C., Sutherland, K. R., Nickols, K. J., and Kaltenberg, A. M. (2012). Biophysical interactions in the plankton: a cross-scale review. Limnol. Oceanogr. Fluids Environ. 2, 121-145.

Proshutinsky, A., Krishfield, R., Timmermans, M.-L., Toole, J., Carmack, E., McLaughlin, F., et al. (2009). Beaufort Gyre freshwater reservoir: state and variability from observations. J. Geophys. Res. 114:C00A10. doi: 10.1029/ 2008jc005104

Rachold, V., Eicken, H., Gordeev, V. V., Grigoriev, M. N., Hubberten, H. W., Lisitzin, A. P., et al. (2004). "Modern terrigenous organic carbon input to the Arctic Ocean," in The organic carbon cycle in the Arctic Ocean, eds R. Stein and R. W. Macdonald (Heidelberg: Springer), 33-55.

Rand, K. M., and Logerwell, E. A. (2011). The first demersal trawl survey of benthic fish and invertebrates in the Beaufort Sea since the late 1970s. Polar Biol. 34, 475-488.

Randelhoff, A., Holding, J., Janout, M., Sejr, M. K., Babin, M., Tremblay, J.-É., et al. (2020). Pan-Arctic Ocean primary production constrained by turbulent nitrate fluxes. Front. Mar. Sci. 7:150. doi: 10.3389/fmars.2020.00150

Randelhoff, A., Reigstad, M., Chierici, M., Sundfjord, A., Ivanov, V., Cape, M., et al. (2018). Seasonality of the physical and biogeochemical hydrography in the inflow to the Arctic Ocean Through Fram Strait. Front. Mar. Sci. 5:224. doi: $10.3389 /$ fmars.2018.00224

Randelhoff, A., and Sundfjord, A. (2018). Short commentary on marine productivity at Arctic shelf breaks: upwelling, advection and vertical mixing. Ocean Sci. 14, 293-300.

Randelhoff, A., Sundfjord, A., and Reigstad, M. (2015). Seasonal variability and fluxes of nitrate in the surface waters over the Arctic shelf slope. Geophys. Res. Lett. 42, 3442-3449. doi: 10.1002/2015GL063655

Ravelo, A. M., Bluhm, B. A., Foster, N., and Iken, K. B. (2020). Biogeography of epibenthic assemblages in the central Beaufort Sea. Mar. Biodivers. 50:8. doi: 10.1007/s12526-019-01036-9

Ravelo, A. M., Konar, B. H., and Bluhm, B. A. (2015). Spatial variability in epibenthic communities on the Alaskan Beaufort Sea shelf. Polar Biol. 38, 1783-1804. doi: 10.1007/s00300-015-1741-9

Renner, A. H. H., Sundfjord, A., Janout, M. A., Ingvaldsen, R. B., BeszczynskaMöller, A., Pickart, R. S., et al. (2018). Variability and redistribution of heat in the Atlantic water boundary current north of Svalbard. J. Geophys. Res. Oceans 123, 6373-6391. doi: 10.1029/2018JC013814

Rippeth, T. P., Lincoln, B. J., Lenn, Y.-D., Green, J. M., Sundfjord, A., and Bacon, S. (2015). Tide-mediated warming of Arctic halocline by Atlantic heat fluxes over rough topography. Nat. Geosci. 8, 191-194. doi: 10.1038/ngeo2350

Rudels, B., Jones, E. P., Anderson, L. G., and Kattner, G. (1994). On the intermediate depth waters of the Arctic Ocean. The Polar Oceans and Their Role in Shaping the Global Environment: The Nansen Centennial Volume. Geophysical Monographs 85. Washington, DC: American Geophysical Union, 33-46.

Rudels, B., Jones, E. P., Schauer, U., and Eriksson, P. (2004). Atlantic sources of the Arctic Ocean surface and halocline waters. Polar Res. 23, 181-208.

Rudels, B., Korhonen, M., Budéus, G., Beszczynska-Möller, A., Schauer, U., Nummelin, A., et al. (2012). The East Greenland Current and its impacts on the Nordic Seas: observed trends in the past decade. ICES J. Mar. Sci. 69, 841-851.

Rudels, B., Korhonen, M., Schauer, U., Pisarev, S., Rabe, B., and Wisotzki, A. (2014). Circulation and transformation of Atlantic water in the Eurasian Basin and the contribution of the Fram Strait inflow branch to the Arctic Ocean heat budget. Prog. Oceanogr. 132, 128-152. doi: 10.1016/j.pocean.2014.04.003

Rudels, B., Schauer, U., Björk, G., Korhonen, M., Pisarev, S., Rabe, B., et al. (2013). Observations of water masses and circulation in the Eurasian Basin of the Arctic Ocean from the 1990s to the late 2000s. Ocean Sci. 9, 147-169.

Schauer, U., Muench, R. D., Rudels, B., and Timokhov, L. (1997). Impact of eastern Arctic shelf waters on the Nansen Basin intermediate layers. J. Geophys. Res. 102, 3371-3382

Schneider, D. (1982). Fronts and seabird aggregations in the southeastern Bering Sea. Mar. Ecol. Prog. Ser. 10, 101-103.

Sentyabov, E. V., and Smirnov, O. V. (2010). Distribution and habitat conditions of Greenland halibut Reinhardtius hippoglossoides in the northwestern part of the Kara Sea. Vopr. Rybolov. 11, 300-312.

Shimada, K., Kamoshida, T., Itoh, M., Nishino, S., Carmack, E., McLaughlin, F., et al. (2006). Pacific Ocean inflow: influence on catastrophic reduction of sea ice cover in the Arctic Ocean. Geophys. Res. Lett. 33:L08605. doi: 10.1029/ 2005GL025624

Slagstad, D., Ellingsen, I. H., and Wassmann, P. (2011). Evaluating primary and secondary production in an Arctic Ocean void of summer sea ice: an experimental simulation approach. Prog. Oceanogr. 90, 117-131.

Slagstad, D., Wassmann, P., and Ellingsen, I. H. (2015). Physical constrains and productivity in the future Arctic Ocean. Front. Mar. Sci. 2:85. doi: 10.3389/ fmars.2015.00085

Smoot, C. A., and Hopcroft, R. R. (2017). Depth-stratified community structure of Beaufort Sea slope zooplankton and its relations to water masses. J. Plankton Res. 39, 79-91.

Soltwedel, T., Jaeckisch, N., Ritter, N., Hasemann, C., Bergmann, M., and Klages, M. (2009). Bathymetric patterns of megafaunal assemblages from the arctic deep-sea observatory HAUSGARTEN. Deep-Sea Res. I Oceanogr. Res. Pap. 56, 1856-1872.

Spall, M., Pickart, R. S., Li, M., Itoh, M., Lin, P., Kikuchi, T., et al. (2018). Transport of Pacific Water into the Canada Basin and the formation of the Chukchi Slope Current. J. Geophys. Res. Oceans 123, 7453-7471.

Spall, M. A., Pickart, R. S., Brugler, E. T., Moore, G. W. K., Thomas, L., and Arrigo, K. R. (2014). Role of shelfbreak upwelling in the formation of a massive under-ice bloom in the Chukchi Sea. Deep-Sea Res. I Oceanogr. Res. Pap. 105, $17-29$.

Springer, A. M., McRoy, C. P., and Flint, M. V. (1996). The Bering Sea Green Belt: shelf-edge processes and ecosystem production. Fish. Oceanogr. 5, 205-223.

Stafford, K. M., Ferguson, M. C., Hauser, D. D., Okkonen, S. R., Berchok, C. L., Citta, J. J., et al. (2018). Beluga whales in the western Beaufort Sea: current state of knowledge on timing, distribution, habitat use and environmental drivers. Deep-Sea Res. II Top. Stud. Oceanogr. 152, 182-194.

Stein, D. L., Felley, J. D., and Vecchione, M. (2005). ROV observations of benthic fishes in the Northwind and Canada Basins, Arctic Ocean. Polar Biol. 28, 232-237.

Storrie, L., Lydersen, C., Andersen, M., Wynn, R. B., and Kovacs, K. M. (2018). Determining the species assemblage and habitat use of cetaceans in the Svalbard Archipelago, based on observations from 2002 to 2014. Polar Res. 37:1463065.

Stroeve, J. C., Kattsov, V., Barrett, A. P., Serreze, M. C., Pavlova, T., Holland, M. M., et al. (2012). Trends in Arctic sea ice extent from CMIP5, CMIP3 and observations. Geophys. Res. Lett. 39:L16502. doi: 10.1029/2012GL052676

Sutherland, D., and Pickart, R. (2008). The East Greenland Coastal Current: Structure, variability and forcing. Prog. Oceanogr. 78, 58-77.

Suzuki, K. W., Bouchard, C., Robert, D., and Fortier, L. (2015). Spatiotemporal occurrence of summer ichthyoplankton in the southeast Beaufort Sea. Polar Biol. 38, 1379-1389.

Svensen, C., Halvorsen, E., Vernet, M., Franze, G., Dmoch, K., Lavrentyev, P., et al. (2019). Zooplankton communities associated with new and regenerated primary production in the Atlantic inflow north of Svalbard. Front. Mar. Sci. 6:293. doi: 10.3389/fmars.2019.00293

Sverdrup, H. U., Johnson, M. W., and Fleming, R. H. (1942). The Oceans: Their Physics, Chemistry and General Biology. New York, NY: Prentice Hall.

Timmermans, M.-L., Garrett, C., and Carmack, E. (2003). The thermohaline structure and evolution of the deep waters in the Canada Basin, Arctic Ocean. Deep-Sea Res I Oceanogr. Res. Pap. 50, 1305-1321. 
Torres-Valdés, S., Tsubouchi, T., Bacon, S., Naveira-Garabato, A. C., Sanders, R., McLaughlin, F. A., et al. (2013). Export of nutrients from the Arctic Ocean. J. Geophys. Res. Oceans 118, 1625-1644. doi: 10.1002/jgrc.20063

Tremblay, J.-É., Bélanger, S., Barber, D. G., Asplin, M., Martin, J., Darnis, G., et al. (2011). Climate forcing multiplies biological productivity in the coastal Arctic Ocean. Geophys. Res. Lett. 38:L18604. doi: 10.1029/2011GL048825

Tremblay, T. E., Raimbault, P., Garcia, N., Lansard, B., Babin, M., and Gagnon, J. (2014). Impact of river discharge, upwelling and vertical mixing on the nutrient loading and productivity of the Canadian Beaufort shelf. Biogeosciences 11, 4853-4868.

Trudnowska, E., Gluchowska, M., Beszczynska-Möller, A., Blachowiak-Samolyk, K., and Kwasniewski, S. (2016). Plankton patchiness in the Polar Front region of the West Spitsbergen Shelf. Mar. Ecol. Prog. Ser. 560, 1-18.

Tverberg, V., and Nøst, O. A. (2009). Eddy overturning across a shelf edge front: Kongsfjorden, west Spitsbergen. J. Geophys. Res. Oceans 114:C04024.

Untersteiner, N. (1988). On the ice and heat balance in Fram Strait. J. Geophys. Res. 527-531.

Uspenskiy, S. M. (1973). Homeland of the Polar Bears. Moscow: Nauks Publishers.

Vacquié-Garcia, J., Lydersen, C., Marques, T. A., Aars, J., Ahonen, H., SkernMauritzen, M., et al. (2017). Late summer distribution and abundance of ice-associated whales in the Norwegian High Arctic. Endanger. Species Res. 32, 59-70. doi: 10.3354/esr00791

Våge, K., Pickart, R. S., Pavlov, V., Lin, P., Torres, D. J., Ingvaldsen, R. B., et al. (2016). The Atlantic water boundary current in the Nansen basin: transport and mechanisms of lateral exchange. J. Geophys. Res. Oceans 121, 6946-6960. doi: 10.1002/2016JC011715

Vanreusel, A., Clough, L., Jacobsen, K., Ambrose, W., Jivaluk, J., Ryheul, V., et al. (2000). Meiobenthos of the central Arctic Ocean with special emphasis on the nematode community structure. Deep-Sea Res. I Oceanogr. Res. Pap. 47, 1855-1879.

Vedenin, A., Gusky, M., Gebruk, A., Kremenetskaia, A., Rybakova, E., and Boetius, A. (2018). Spatial distribution of benthic macrofauna in the Central Arctic Ocean. PLoS One 13:e0200121. doi: 10.1371/journal.pone.0200121

von Appen, W. J., and Pickart, R. S. (2012). Two configurations of the western Arctic shelfbreak current in summer. J. Phys. Oceanogr. 42, 329-351.

Walsh, D., Polyakov, I., Timokhov, L., and Carmack, E. (2007). Thermohaline structure and variability in the eastern Nansen Basin as seen from historical data. J. Mar. Res. 65, 685-714.

Wassmann, P., Carmack, E., Kosobokova, K. N., Slagstad, D., Drinkwater, K., Hopcroft, R. R., et al. (2015). The contiguous domains of Arctic Ocean advection: trails of life and death. Prog. Oceanogr. 139, 42-65. doi: 10.1016/j. pocean.2015.06.011

Wassmann, P., Slagstad, D., and Ellingsen, I. (2019). Advection of mesozooplankton into the northern Svalbard shelf region. Front. Mar. Sci. 6:458. doi: 10.3389/fmars.2019.00458

Wei, C.-K., Rowe, G. T., Escobar-Briones, E., Boetius, A., Soltwedel, T., Caley, M. J., et al. (2010). Global patterns and predictions of seafloor biomass using random forests. PLoS One 5:e15323. doi: 10.1371/journal.pone.0015323

Weingartner, T., Aagaard, K., Woodgate, R., Danielson, S., Sasaki, Y., and Cavalieri, D. (2005). Circulation on the north central Chukchi Sea shelf. Deep-Sea Res. I Oceanogr. Res. Pap. 52, 3150-3174. doi: 10.1016/j.dsr2.2005.10.015

Weingartner, T. J., Fang, Y.-C., Winsor, P., Dobbins, E., Potter, R., Statscewich, H., et al. (2017). The summer hydrographic structure of the Hanna Shoal region on the northeastern Chukchi Sea shelf: 2011-2013. Deep-Sea Res. I Oceanogr. Res. Pap. 144, 6-20. doi: 10.1016/j.dsr2.2017.08.006

Wiedmann, I., Ershova, E., Bluhm, B. A., Nöthig, E.-M., Gradinger, R. R., Kosobokova, K., et al. (2020). What feeds the benthos of the Arctic Basins? Assembling a carbon budget for the deep Arctic Ocean. Front. Mar. Sci. 7:224. doi: 10.3389/fmars.2020.00224

Wilkinson, B. P., Jahncke, J., Warzybok, P., Bradley, R. W., and Shaffer, S. A. (2018). Variable utilization of shelf break-associated habitats by chick-brooding rhinoceros auklets In the California Current system. Mar. Ecol. Prog. Ser. 590, 2011-2226.

Williams, W. J., and Carmack, E. C. (2008). Combined effect of wind-forcing and isobath divergence on upwelling at Cape Bathurst, Beaufort Sea. J. Mar. Res. 66, $645-663$.

Williams, W. J., and Carmack, E. C. (2015). The 'interior' shelves of the Arctic Ocean: physical oceanographic setting, climatology and effects of sea-ice retreat on cross-shelf exchange. Prog. Oceanogr. 139, 24-41.

Williams, W. J., Carmack, E. C., Shimada, K., Melling, H., Aagaard, K., Macdonald, R. W., et al. (2006). Joint effects of wind and ice motion in forcing upwelling in Mackenzie Trough, Beaufort Sea. Cont. Shelf Res. 26, 2352-2366.

Williams, W. J., Melling, H., Carmack, E. C., and Ingram, R. G. (2008). Kugmallit Valley as a conduit for cross-shelf exchange on the Mackenzie Shelf in the Beaufort Sea. J. Geophys. Res. Oceans 113:C02007.

Wlodarska-Kowalczuk, M., Kendall, M. A., Weslawski, J. M., Klages, M., and Soltwedel, T. (2004). Depth gradients of benthic standing stock and diversity on the continental margin at a high-latitude ice-free site (off Spitsbergen, $79 \mathrm{~N}$ ). Deep-Sea Res. I Oceanogr. Res. Pap. 51, 1903-1914.

Woodgate, R. A. (2018). Increases in the Pacific inflow to the Arctic from 1990 to 2015, and insights into seasonal trends and driving mechanisms from yearround Bering Strait mooring data. Prog. Oceanogr. 160, 124-154. doi: 10.1016/ j.pocean.2017.12.007

Woodgate, R. A., Aagaard, K., and Weingartner, T. J. (2006). Interannual changes in the Bering Strait fluxes of volume, heat and freshwater between 1991 and 2004. Geophys. Res. Lett. 33:L15609.

Zhong, W., Steele, M., Zhang, J., and Cole, S. T. (2019). Circulation of Pacific Winter Water in the Western Arctic Ocean. J. Geophys. Res. Oceans 124, 863-881. doi: 10.1029/2018JC014604

Zhulay, I., Iken, K., Renaud, P., and Bluhm, B. A. (2019). Epifaunal community across marine landscapes of the deep Chukchi Borderland (Pacific Arctic). Deep-Sea Res. I Oceanogr. Res. Pap. 151:103065. doi: 10.1016/j.dsr.2019. 06.011

Conflict of Interest: The authors declare that the research was conducted in the absence of any commercial or financial relationships that could be construed as a potential conflict of interest.

Copyright (C) 2020 Bluhm, Janout, Danielson, Ellingsen, Gavrilo, Grebmeier, Hopcroft, Iken, Ingvaldsen, Jørgensen, Kosobokova, Kwok, Polyakov, Renaud and Carmack. This is an open-access article distributed under the terms of the Creative Commons Attribution License (CC BY). The use, distribution or reproduction in other forums is permitted, provided the original author(s) and the copyright owner(s) are credited and that the original publication in this journal is cited, in accordance with accepted academic practice. No use, distribution or reproduction is permitted which does not comply with these terms. 